\title{
A review of advances in the understanding of lupus nephritis pathogenesis as a basis for emerging therapies [version 1;
}

\section{peer review: 2 approved]}

\author{
Susan Yung*, Desmond YH Yap*, Tak Mao Chan (10 \\ Department of Medicine, The University of Hong Kong, Pokfulam, Hong Kong \\ ${ }^{*}$ Equal contributors
}

V1 First published: 04 Aug 2020, 9(Faculty Rev):905

https://doi.org/10.12688/f1000research.22438.1

Latest published: 04 Aug 2020, 9(Faculty Rev):905

https://doi.org/10.12688/f1000research.22438.1

\begin{abstract}
Lupus nephritis is an important cause of both acute kidney injury and chronic kidney disease that can result in end-stage renal disease. Its pathogenic mechanisms are characterized by aberrant activation of both innate and adaptive immune responses, dysregulation of inflammatory signaling pathways, and increased cytokine production. Treatment of lupus nephritis remains a challenging issue in the management of systemic lupus erythematosus since the clinical presentation, response to treatment, and prognosis all vary considerably between patients and are influenced by ethnicity, gender, the degree of chronic kidney damage, pharmacogenomics, and non-immunological modulating factors. Elucidation of the various immunopathogenic pathways in lupus nephritis has resulted in the development of novel therapies, including biologics that target specific antigens on B lymphocytes to achieve B cell depletion, agents that modulate B cell proliferation and development, drugs that block co-stimulatory pathways, drugs that target T lymphocytes primarily, and therapies that target complement activation, signaling pathways, pro-inflammatory cytokines, and neutrophil extracellular traps. This review will discuss recent advances in the understanding of disease pathogenesis in lupus nephritis in the context of potential emerging therapies.
\end{abstract}

\section{Keywords}

lupus nephritis, lupus nephritis pathogenesis, inflammation, B cell depletion, emerging therapies

\section{Open Peer Review \\ Approval Status \\ 1 \\ 2 \\ version 1 \\ 04 Aug 2020 \\ Faculty Reviews are review articles written by the prestigious Members of Faculty Opinions. The articles are commissioned and peer reviewed before publication to ensure that the final, published version is comprehensive and accessible. The reviewers who approved the final version are listed with their names and affiliations.}

1. Richard Furie, Northwell Health, Great Neck, USA

2. Scott E. Wenderfer, Baylor College of Medicine, Texas Children's Hospital, Houston, USA

Any comments on the article can be found at the end of the article. 
Corresponding author: Tak Mao Chan (dtmchan@hku.hk)

Author roles: Yung S: Writing - Original Draft Preparation; Yap DY: Writing - Original Draft Preparation; Chan TM: Conceptualization, Funding Acquisition, Writing - Review \& Editing

Competing interests: No competing interests were disclosed.

Grant information: Studies undertaken by T. M. Chan's group were funded by the RGC General Research Fund (HKU 7550/06M), UGC Matching Grant Scheme (Phases V and VI), the Department of Medicine Academic Activities Fund and kind donations from Mr C. S. Yung, Mr S. Ho, the Hui Hoy \& Chow Sin Lan Charity Fund, and the family of Mr Hui Ming. S. Yung is supported by the Endowment Fund established for the 'Yu Chiu Kwong Professorship in Medicine' awarded to T. M. Chan and the Wai Hung Charitable Foundation Limited. The funders had no role in study design, data collection and analysis, decision to publish, or preparation of the manuscript.

Copyright: (c) 2020 Yung S et al. This is an open access article distributed under the terms of the Creative Commons Attribution License, which permits unrestricted use, distribution, and reproduction in any medium, provided the original work is properly cited.

How to cite this article: Yung S, Yap DY and Chan TM. A review of advances in the understanding of lupus nephritis pathogenesis as a basis for emerging therapies [version 1; peer review: 2 approved] F1000Research 2020, 9(Faculty Rev):905

https://doi.org/10.12688/f1000research.22438.1

First published: 04 Aug 2020, 9(Faculty Rev):905 https://doi.org/10.12688/f1000research.22438.1 


\section{Introduction}

Kidney involvement, termed lupus nephritis (LN), is one of the most severe forms of organ involvement in systemic lupus erythematosus (SLE) as reflected by the associated morbidities, its detrimental effects on patient and kidney survival, and the quantity of immunosuppressive agents required for treatment ${ }^{1,2}$. The resultant chronic kidney damage and the exposure to toxic medications are also significant contributors to reduced survival of patients even after successful treatment of active nephritis. The pathogenesis of LN encompasses a loss of self-tolerance, aberrant activation of both innate and adaptive immune responses, autoantibody production, and immune-mediated kidney injury. LN is characterized by episodic flares separated by variable durations of disease quiescence. Even when immunosuppressive treatments are successful in inducing remission, the cumulative kidney damage resulting from repeated nephritic flares, as evident from glomerulosclerosis, fibrous crescents, tubular atrophy, and interstitial fibrosis in the kidney biopsy, portends progressive chronic kidney disease eventually culminating in end-stage renal failure ${ }^{3}$. The goals of clinical management therefore include early detection and prompt and effective treatment of acute nephritic flares as well as the prevention of relapses. The efficacy and tolerability of current immunosuppressive treatments for $\mathrm{LN}$ vary between patients and are influenced by multiple factors including race and renal reserve. In addition, corticosteroids remain a mainstay of treatment but are associated with considerable short-term and long-term toxicities related to non-specific anti-inflammatory and immunosuppressive actions. It is against this background that the search for novel therapies has continued with the aim of adding new treatments with increased levels of safety, often related to increased specificity in intercepting crucial pathogenic pathway(s), to the therapeutic armamentarium. This review presents a brief overview of recent knowledge in the pathogenesis of $\mathrm{LN}$ in the context of potential emerging therapies (Figure 1) (Table 1).

\section{B lymphocytes in the pathogenesis of lupus nephritis} The etiology of LN is complex and multi-factorial and involves the interplay between genetic predisposition and environmental and hormonal factors ${ }^{4-7}$. $\mathrm{LN}$ is characterized by the production of autoantibodies against a broad diversity of autoantigens, in particular against chromatin material such as double-stranded (ds) DNA and nucleosomes resulting from defective clearance of apoptotic material ${ }^{8}$, and necrotic cells that release cellular

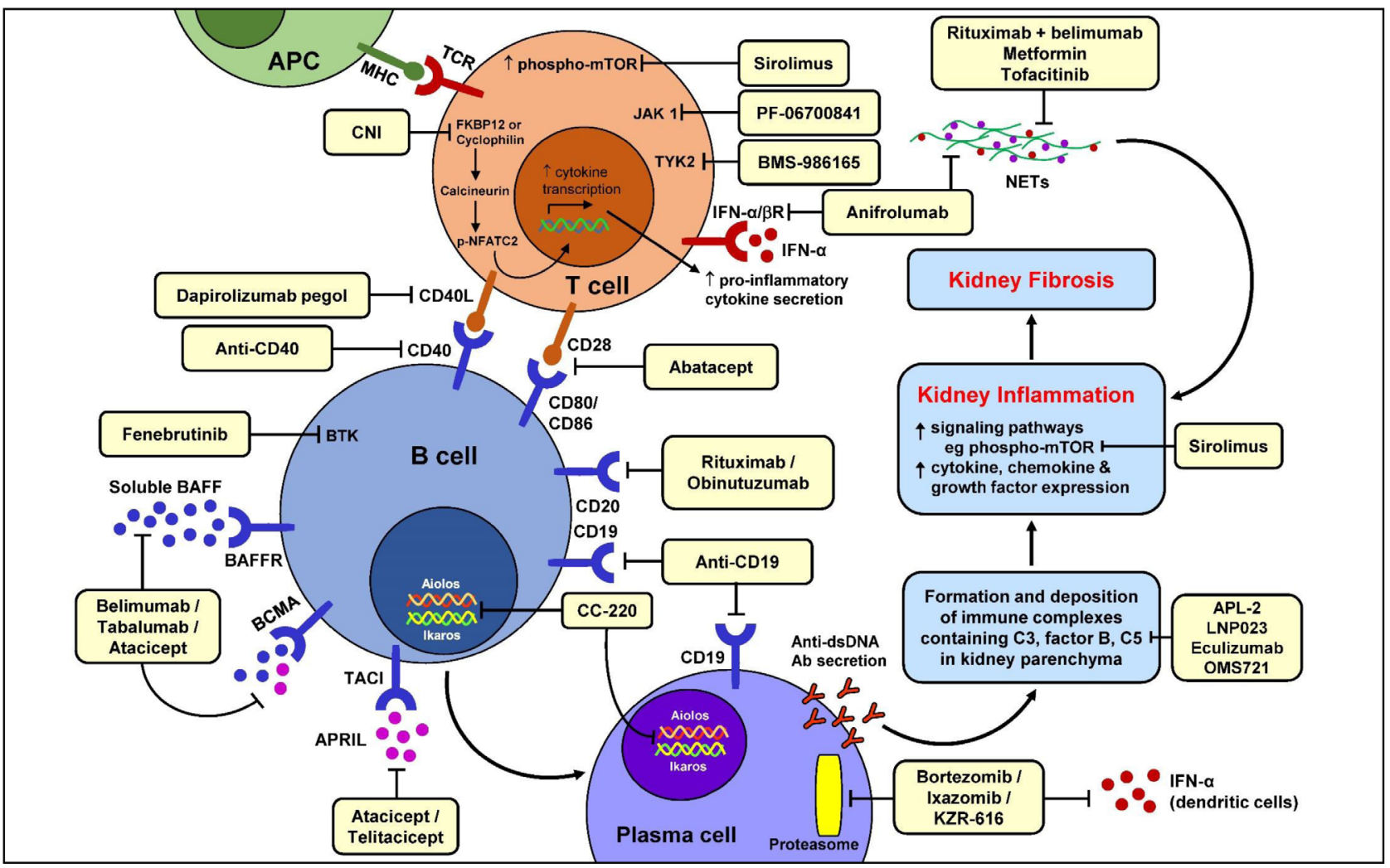

Figure 1. Schematic diagram showing the immunopathogenic pathways leading to kidney damage in lupus nephritis and emerging novel therapies targeting specific pathways. Ab, antibody; APC, antigen presenting cell; APRIL, a proliferating-inducing ligand; BAFF, B cell activating factor; BAFFR, B cell activating factor receptor; BCMA, B cell maturation antigen; BTK, Bruton's tyrosine kinase; C3, complement 3; C5, complement 5; CD, cluster of differentiation; CNI, calcineurin inhibitor; ds, double-stranded; FKBP12, FK506-binding protein; IFN, interferon; IFN $\alpha / \beta R$, interferon- $\alpha / \beta$ receptor; JAK, Janus kinase; MHC, major histocompatibility complex; mTOR, mammalian or mechanistic target of rapamycin; NETs, neutrophil extracellular traps; NFATC2, nuclear factor of activated T cells 2; TACI, transmembrane activator and calcium modulator and cyclophilin ligand interactor; TCR, T cell receptor; TYK2, tyrosine kinase-2. 


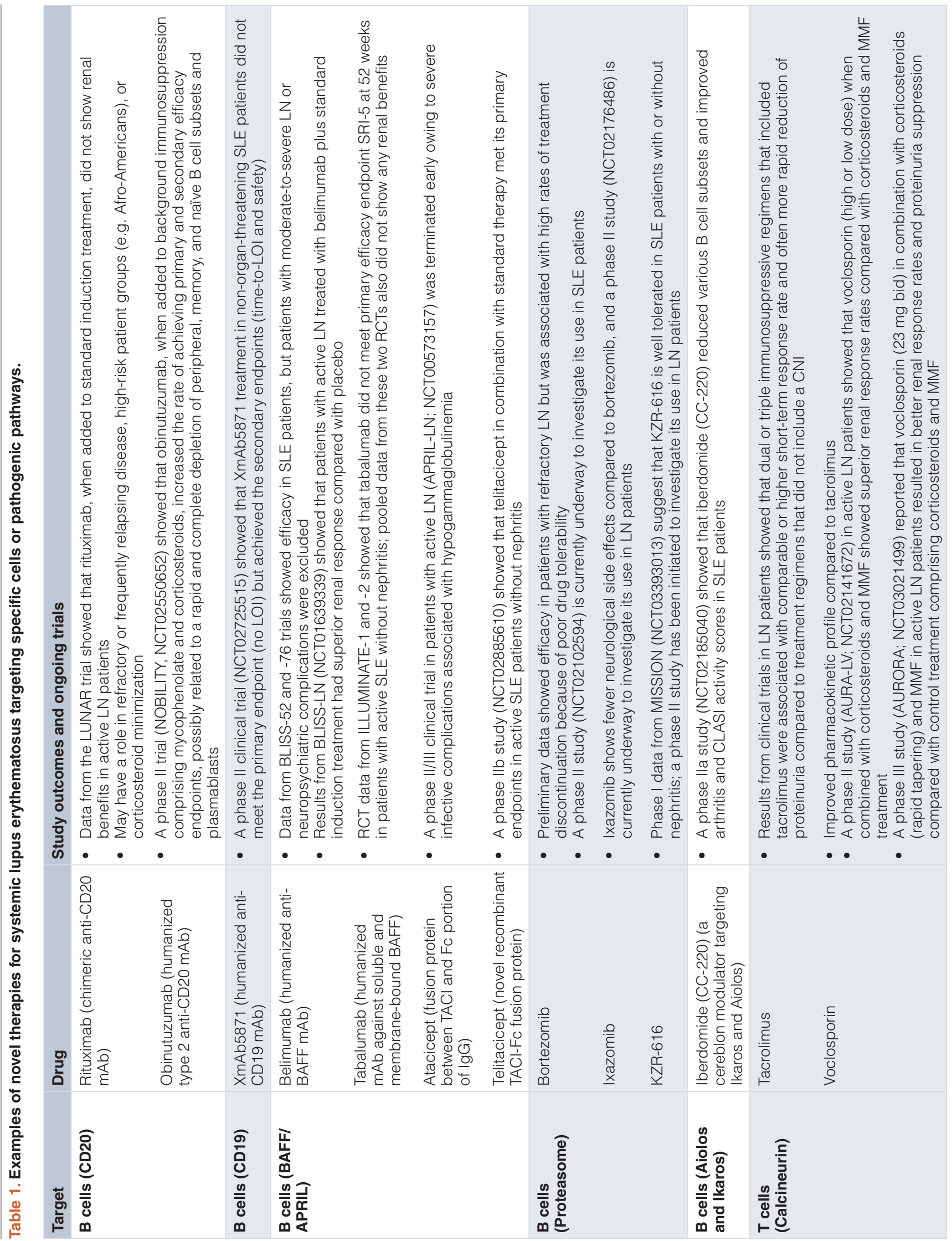




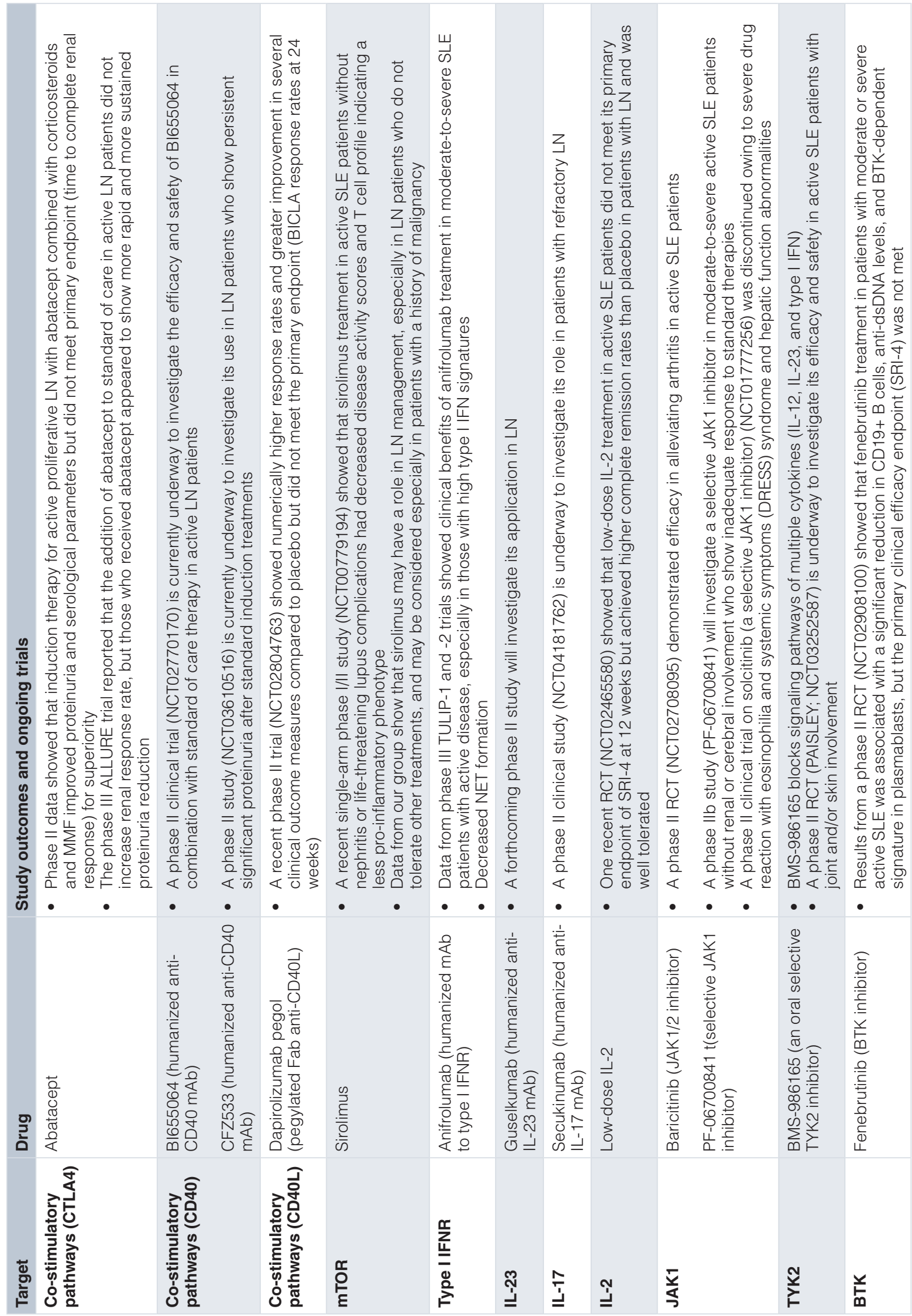




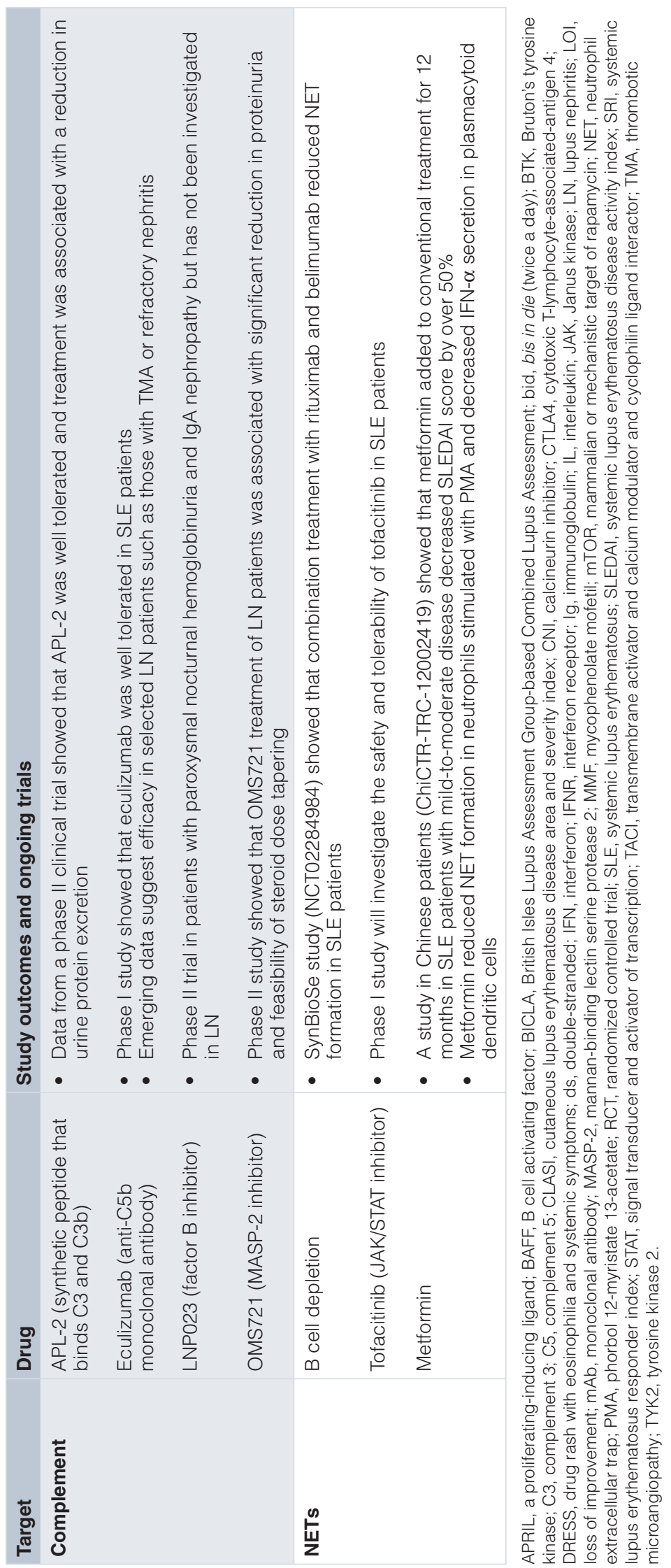


components which may form neoantigens. The release of DNA/protein and RNA/protein from dying cells activates dendritic cells, monocytes, and macrophages through Toll-like receptor (TLRs), resulting in the secretion of pro-inflammatory mediators, such as interferon (IFN)- $\alpha$, tumor necrosis factor (TNF)- $\alpha$, and interleukin (IL)-6, which activate effector $T$ cells and $\mathrm{B}$ cells. Aberrant $\mathrm{T}$ cell activation and the prolonged survival and maturation process of $\mathrm{B}$ cells result in increased numbers of autoreactive B cells, memory B cells, and plasma cells. Abnormalities in B cell biology in SLE include early entrance of immature, transitional, and naïve B cells to mature B cells, attributed in part through increased expression of B-cell-activating factor (BAFF), a cytokine that promotes B cell survival from late transitional stage to mature and memory B cells. FcyRIIIB expression is reduced in SLE patients compared to healthy subjects, resulting in the persistence of autoreactive $\mathrm{B}$ cells. Also, memory B cells in SLE patients show reduced FcyRIIB expression and a lower threshold for reactivation'. B cells derived from SLE patients exhibit increased somatic hypermutation and class-switch recombination, resulting in enhanced pathogenicity of plasma cells $\mathrm{s}^{10-12}$. Autoantibodies produced by plasma cells in LN patients are usually of the immunoglobulin (Ig) G subclass, and the isotype can be related to the nature of the respective antigen. For example, protein and polysaccharide antigens have been shown to induce $\operatorname{IgG} 1$ and $\operatorname{IgG} 2$, respectively ${ }^{13}$. Also, pro-inflammatory cytokines such as IL-4 and IL-21 can induce isotype switching ${ }^{13,14}$. In this regard, IgG1 and IgG3 bind FcyR more efficiently to trigger complement activation, downstream inflammatory processes, immune complex deposition, and tissue injury.

\section{Emerging therapies targeting $B$ lymphocytes}

As described previously, B cells are promising therapeutic targets of LN since they are central to pathogenesis ${ }^{15,16}$. The pathogenic role of $\mathrm{B}$ cells is not just limited to autoantibody production but extends to antigen presentation, $\mathrm{T}$ cell activation and polarization, modulation of dendritic cell maturation, and cytokine secretion ${ }^{15,16}$. The survival and maturation of $\mathrm{B}$ cells at different stages of development depend on the delivery of survival and trophic signals through cell surface ligands such as BAFF, CD19, and CD20. These cell surface antigens may thus serve as therapeutic targets for B cell depletion in the treatment of SLE and LN.

\section{Rituximab}

CD20 is a specific B cell surface antigen that promotes differentiation and activation. It is expressed on immature, mature, and activated B cells and is absent on hematopoietic stem cells, pro-B cells, and plasma cells ${ }^{17,18}$. Rituximab is a type I chimeric IgG1 mouse/human monoclonal antibody directed against CD20, and it depletes B cells, thus diminishing their differentiation into plasma cells, and therefore decreases autoantibody production ${ }^{19}$. Rituximab was originally approved for the treatment of relapsed or refractory, low-grade or follicular, $\mathrm{CD} 20^{+} \mathrm{B}$ cell non-Hodgkin lymphoma, and its use has been extended to various autoimmune diseases such as rheumatoid arthritis, ANCA-associated vasculitis, and primary immune thrombocytopenic purpura ${ }^{20}$. Crosslinking of CD20 molecules by rituximab induces the redistribution of CD20 into membrane microdomains known as lipid rafts and the formation of antigen-antibody complexes, leading to $\mathrm{CD} 20^{+} \mathrm{B}$ cell apoptosis through three mechanisms, namely complement-dependent cytotoxicity, antibody-dependent cell-mediated cytotoxicity, and, to a lesser extent, direct signaling through CD20. Rituximab eliminates peripheral B cells without suppressing their regeneration from B cell precursors, and, by sparing plasma cells, has no immediate effect on Ig level. In preclinical studies, treatment of New Zealand black and white, first generation (NZB/W F1) mice with anti-CD20 antibodies before the onset of proteinuria delayed disease onset, whereas treatment after onset of nephritis reduced disease progression, suggesting that $\mathrm{B}$ cells are critical to both the initiation and the maintenance of disease $^{21}$. There is also a subset-associated hierarchy of B cell sensitivity to depletion by rituximab, with peripheral blood B cells being the most sensitive, and B cells in the spleen, lymph node, or bone marrow being less sensitive, which could be related to relatively low tissue penetration by the antibody. Despite its primary action on B cells, the $\mathrm{B}$ cell depletion that resulted from treatment with rituximab was associated with a reduction in $\mathrm{T}$ cell memory and activation. Some NZB/W F1 mice appeared to be resistant to the $\mathrm{B}$ cell-depleting action of rituximab, which was attributed to a rapid clearance of circulating anti-CD20 antibodies and/or increased BAFF secretion ${ }^{21}$.

Data from the LUNAR trial showed that rituximab, when added to standard induction immunosuppressive regimens, did not increase the rate of renal response, despite leading to more pronounced improvements in serological parameters and proteinuria $^{22}$. Proposed explanations for this apparent paradox include the efficacy of background immunosuppression, suboptimal depletion of tissue-infiltrating B cells and plasma cells, increased BAFF secretion, and inadequate sensitivity of clinical efficacy endpoints. Lack of treatment efficacy could also be related to monoclonal antibody metabolism, reduced antibody binding due to FcyRIII polymorphism, complement depletion, increased expression of complement inhibitory molecules such as CD55 and CD59, abnormal lipid raft composition, or limited access to the parenchyma of solid organs ${ }^{23,24}$. In this regard, B cells are present in the tubulo-interstitium and contribute to local inflammation and kidney injury ${ }^{25}$. It is currently unknown to what degree rituximab can directly deplete $\mathrm{B}$ cells in the kidney. Another mechanism for rituximab resistance may involve the upregulation of CD46, a key surface protein that inhibits complement activation. Serum CD46 level, possibly a product of proteolytic cleavage from apoptotic cell membranes, is increased in SLE patients with active disease compared to patients with inactive disease ${ }^{26,27}$. Whether combination therapy targeting both CD46 and CD20 may increase efficacy remains to be investigated. Despite the negative results in pivotal trials, rituximab is commonly used in the management of SLE patients, including patients with $\mathrm{LN}$, in view of the favorable real-world clinical experience in severe renal or extra-renal manifestations and its relatively low toxicity, especially in patients who have an inadequate response to or who cannot tolerate standard therapies. Results from post-hoc analysis of the LUNAR trial also suggested that it may be particularly useful in high-risk patient groups such as Afro-Americans ${ }^{28-32}$. 


\section{Obinutuzumab}

Obinutuzumab is a glycoengineered, type II, humanized antiCD20 antibody developed to treat lymphoproliferative disorders and to alleviate several mechanisms which could lead to treatment resistance. Obinutuzumab has no fucosylated sugars on the $\mathrm{Fc}$ portion and demonstrates enhanced binding affinity to the FcyRIII receptor on immune effector cells ${ }^{24}$. Obinutuzumab is more effective than rituximab in inducing direct B cell death and antibody-dependent cellular cytotoxicity and phagocytosis. Unlike rituximab, it does not relocalize CD20 to lipid rafts and its effect on B cell depletion is not influenced by complement protein exhaustion or complementinhibiting factor ${ }^{24}$. Pre-clinical data showed the superior efficacy of obinutuzumab in B cell depletion compared with rituximab $^{24}$. Recent results from the phase II NOBILITY study (NCT02550652) showed that obinutuzumab, when added to background immunosuppression comprising corticosteroids and mycophenolate, increased the rates of achieving primary and secondary efficacy endpoints, possibly related to a rapid and complete depletion of peripheral, memory, and naïve B cell subsets and plasmablasts ${ }^{33,34}$.

\section{Belimumab and agents that target the BAFF/APRIL pathway}

BAFF and a proliferation-inducing ligand (APRIL) are transmembrane proteins of the TNF family synthesized by myeloid cells. They can be proteolytically cleaved from the cell and exist in soluble form. BAFF and APRIL bind to receptors such as transmembrane activator and calcium modulator and cyclophilin ligand interactor (TACI) and B-cell maturation antigen (BCMA). BAFF and APRIL are required for B cell survival from their initial development to terminal differentiation. BAFF promotes the survival and maturation of transitional $\mathrm{B}$ cells into mature B cells and supports B cell proliferation, plasma cell survival, and class-switch recombination. APRIL also promotes cell survival and class-switch recombination and plays an important role in $\mathrm{T}$ cell-independent responses ${ }^{13}$. Inhibition of B cell survival factors represents an alternative approach to inhibit B cell and humoral immune responses. Belimumab is a human $\operatorname{IgG} 1 \lambda$ antibody that blocks the bioactivity of soluble BAFF, thus inhibiting B cell survival and differentiation. Results from two randomized controlled trials (RCTs), BLISS-52 and BLISS-76, demonstrated the efficacy of belimumab in active SLE patients, but patients with moderate or severe LN or neuropsychiatric complications were excluded from these trials ${ }^{35,36}$. Post-hoc analysis of the pooled data from these trials suggested an efficacy of belimumab treatment on renal manifestations and a decreased incidence of renal flare in patients who received belimumab ${ }^{37}$. Whether the latter could be explained by sustained inhibition of memory $\mathrm{B}$ cells and plasma cells remains speculative ${ }^{38}$. A phase III clinical trial which investigated the efficacy of belimumab in LN (BLISS-LN; NCT01639339) was completed recently, and the results showed that a higher number of patients met its primary and secondary endpoints when treated with belimumab plus standard induction therapy compared to placebo and standard induction therapy ${ }^{39}$.

While data on belimumab in SLE and LN appear to be encouraging, other anti-BAFF therapies have failed to demonstrate efficacy in clinical trials. Results from the ILLUMINATE-1 and -2 trials showed that treatment with tabalumab, a monoclonal antibody against both soluble and membrane-bound BAFF, did not meet the primary efficacy endpoint of SLE responder index (SRI)-5 in patients with active SLE but no renal involvement ${ }^{40,41}$, and pooled data from these two RCTs did not suggest beneficial effects of tabalumab on the renal outcomes ${ }^{42}$. Atacicept is a human recombinant fusion protein of TACI and the Fc portion of IgG1. The APRIL-LN trial (NCT00573157), which aimed to investigate the role of atacicept in the treatment of active LN, was terminated early because of severe infective complications associated with low serum Ig level in the first few treated patients ${ }^{43}$. Telitacicept, also known as RC18, is a novel recombinant TACI-Fc fusion protein that targets and inhibits BLyS (aka BAFF) and APRIL and suppresses the development and survival of plasma cells and mature B cells. A recent phase IIb study (NCT02885610) demonstrated that telitacicept in combination with standard therapy met its primary endpoint in active SLE patients without nephritis ${ }^{44}$. Sequential rituximab-belimumab treatment in patients with active $\mathrm{LN}$ is a therapeutic approach currently being investigated (CALIBRATE; NCT02260934), aiming to ensure adequate $\mathrm{B}$ cell suppression by first depletion and then preventing their repopulation using belimumab ${ }^{45}$. Interim data from the CALIBRATE study showed that despite B cell depletion and delayed circulating $\mathrm{B}$ cell reconstitution, sequential rituximab-belimumab treatment did not improve clinical outcome ${ }^{45}$. Results from the SynBioSe study (NCT02284984) demonstrated that combination treatment with rituximab and belimumab in SLE patients with severe and refractory disease improved clinical outcome, and this was associated with decreased production of neutrophil extracellular traps (NETs) ${ }^{46}$. A phase II clinical trial (SynBioSe-2; NCT03747159) will investigate the efficacy of belimumab followed by rituximab in LN patients. A phase III clinical trial (BLISS-BELIEVE; NCT03312907) investigating the efficacy and safety of belimumab administered in combination with rituximab in patients with active SLE is ongoing ${ }^{47}$. Another ongoing study (phase II; NCT04058028) is investigating the use of BAFF/inducible T-cell co-stimulator ligand (ICOSL) bispecific antibody in active SLE patients without recent cerebral or renal involvement.

\section{Other therapies targeting B cells or plasma cells}

$\mathrm{B}$ cell depletion can also be achieved by monoclonal antibodies binding to other B cell surface molecules such as CD19 (XmAb5871). In a recent phase II clinical trial (NCT02725515), XmAb5871 treatment of non-organ-threatening SLE patients did not meet the primary endpoint of "no loss of improvement (LOI)" but achieved the secondary endpoint of "time-to-LOI and safety" ${ }^{48}$. Emerging evidence suggests that proteasome inhibitors such as bortezomib and ixazomib (an oral proteasome inhibitor with fewer neurological complications, such as a lower risk of peripheral neuropathy) can target plasma cells through binding to $26 \mathrm{~S}$ proteasome and inhibiting its chymotrypsin-like activity and inactivating the nuclear factor kappa-light chain enhancer of activated B cell process. Preliminary clinical experience showed the efficacy of bortezomib in active LN patients who were refractory to conventional induction therapies ${ }^{49,50}$, although the high rates of treatment discontinuation due to poor drug 
tolerability remains a concern. Phase II clinical studies are currently underway to investigate the use of bortezomib in SLE patients (NCT02102594) and ixazomib in LN patients (NCT02176486). The MISSION study (NCT03393013) is a phase $\mathrm{Ib} / \mathrm{II}$ trial that investigates the safety and tolerability of KZR-616, a specific immunoproteasome inhibitor, in patients with active SLE with or without LN (phase Ib) or patients with active proliferative LN (phase II). Results from the phase Ib study showed that KZR-616 at a dose of $45 \mathrm{mg}$ SC was safe and well tolerated $^{51}$, and the phase II clinical trial is still ongoing.

Aiolos and Ikaros are members of the Ikaros family of hemopoietic-specific zinc-finger transcription factors that play key roles in the regulation of lymphocyte development and differentiation ${ }^{52,53}$. Ikaros is expressed in pluripotent hemopoietic stem cells and regulates both lymphoid and myeloid cell development. Through its ability to regulate the development of plasmacytoid dendritic cells, Ikaros can also regulate key inflammatory pathways such as signal transducer and activator of transcription (STAT) 4 and IFN- $\alpha$ pathways ${ }^{54}$. Aiolos contributes to B cell development and facilitates the generation of long-lived high-affinity bone marrow plasma cells. Aiolos is weakly expressed in pro-B cells and is increased in pre-B cells and mature peripheral B cells $\mathrm{s}^{55}$. Studies have shown that Aiolos expression is increased in peripheral blood mononuclear cells (PBMCs) from SLE patients compared to healthy subjects $^{56,57}$. CC-220 (iberdomide) is a modulator of the cullin ring ligase 4-cereblon (CRL4 ${ }^{\mathrm{CRBN}}$ ) E3 ubiquitin ligase complex, which induces ubiquitination of the CRBN substrates Aiolos and Ikaros, resulting in their proteasomal degradation. In vitro studies demonstrated that the addition of iberdomide to B cells or PBMCs from SLE patients or healthy subjects, respectively, reduced Aiolos and Ikaros expression and inhibited BAFFinduced $\mathrm{B}$ cell differentiation and the production of anti-dsDNA antibodies and anti-phospholipid antibodies ${ }^{56,57}$. A phase IIa clinical study (NCT02185040), which investigated the tolerability and effect of iberdomide on skin, joint, and serological manifestations in SLE patients, reported that iberdomide significantly reduced B cell subset populations and plasmacytoid dendritic cells and improved arthritis and cutaneous lupus erythematosus disease area and severity index (CLASI) activity score, an assessment score for cutaneous involvement ${ }^{58,59}$. A phase IIb clinical study (NTC03161483) to investigate the efficacy and safety of iberdomide in a larger cohort of patients with active SLE is ongoing.

\section{Emerging therapies targeting T Iymphocytes}

$\mathrm{T}$ lymphocytes in lupus patients exhibit a lower activation threshold compared with $\mathrm{T}$ cells in healthy subjects ${ }^{60}$. $\mathrm{T}$ cell receptor (TCR)-mediated activation results in increased calcium influx and activation of calcineurin, a calcium-calmodulindependent serine-threonine phosphatase. Calcineurin activation leads to nuclear factor of activated T cells (NFAT) dephosphorylation, nuclear translocation of NFAT, and downstream induction of IFN- $\gamma$, TNF- $\alpha$, and IL-2, IL-4, IL-6, and IL-17 ${ }^{61}$. Calcineurin inhibitors (CNIs) such as cyclosporine A (CsA), tacrolimus (TAC), or voclosporin inhibit the T-cell-mediated immune response by binding to cytosolic immunophilins such as cyclophilins or FK506-binding protein (FKBP12), then inhibit calcineurin activity and NFAT dephosphorylation ${ }^{61}$. Triple immunosuppression that includes corticosteroids, CNIs, and mycophenolate is the standard-of-care immunosuppressive regimen to prevent kidney transplant rejection ${ }^{62}$. The same approach has been used in animal studies and clinical practice in the management of SLE. Treatment of MRL/lpr mice with prednisolone, TAC, and mycophenolate showed increased efficacy compared with monotherapy, and transcriptomic analysis demonstrated synergistic actions of the different drugs targeting different disease-relevant pathogenic pathways ${ }^{63}$. In addition to its action on T cells, CNIs modulate the podocyte cytoskeleton through synaptopodinregulated Ras homolog family member A (RhoA) and Ras-related C3 botulinum toxin substrate 1 (Rac1), suppress the dephosphorylation and degradation of synaptopodin, and directly ameliorate the injury to podocyte foot process barrier function ${ }^{64}$. Based on this dual action, CNIs are commonly used in the management of glomerular diseases characterized by persistent proteinuria $^{65}$. Compared with CsA, TAC is associated with less hirsutism and coarsening of facial features. Results from recent clinical trials showed that dual or triple (termed "multitarget" in some studies) immunosuppressive regimens that included TAC or CsA were associated with comparable or higher shortterm response rates, and often more rapid reduction of proteinuria, in the treatment of patients with active severe LN compared to control groups treated with standard immunosuppressive regimens that did not include a $\mathrm{CNI}^{66-73}$. With the level of proteinuria being a key component in the definition of treatment response, the findings are not unanticipated. One should be reminded that proteinuria is but a surrogate biomarker, one that is relatively easy to measure repeatedly, for long-term renal survival ${ }^{74}$, and that the preservation of long-term kidney function is the ultimate objective in LN management ${ }^{75}$. An alternative approach to inclusion of a CNI upfront in the treatment of active nephritis is to add the drug in patients whose proteinuria has not decreased to an acceptable low level after treatment with standard therapies, and our group has reported on the efficacy and safety of long-term TAC treatment adopting this approach ${ }^{76}$. Both CsA and TAC are associated with marked individual variations in pharmacokinetics and the side-effects of nephrotoxicity and hypertension, among others, and discontinuation after a relatively short duration of treatment is associated with a high rate of relapse in proteinuric kidney diseases ${ }^{77,78}$. Questions that need to be answered regarding the role of TAC or CsA in the management of $\mathrm{LN}$ include the optimal level and duration of drug exposure, how to avoid nephrotoxicity, especially in patients with significant chronic kidney disease, and their impact on long-term clinical outcomes.

Voclosporin is a novel calcineurin inhibitor that is an analogue of CsA. Although voclosporin is structurally similar to CsA, a single carbon atom is added to the amino acid-1 region, resulting in enhanced binding to calcineurin and increased potency, faster elimination, and less plasma variation than $\mathrm{CsA}^{79-81}$. In a recent phase II clinical trial in active $\mathrm{LN}$ (AURA-LV; NCT02141672), voclosporin (high or low dose) when combined with corticosteroids and mycophenolate mofetil (MMF) showed superior renal response rates compared with 
corticosteroids and MMF induction at 24 weeks and 48 weeks ${ }^{82}$. A subsequent phase III study (AURORA; NCT03021499) showed that voclosporin $(23.7 \mathrm{mg}$ bid) in combination with $\mathrm{MMF}$ and corticosteroids, the latter adopting a force-tapering reduced-dose regimen, achieved statistically superior and faster renal response rate (defined as a urinary protein-to-creatinine ratio [UPCR] of $\leq 0.5 \mathrm{mg} / \mathrm{mg}$ and an estimated glomerular filtration rate [eGFR] of $\geq 60 \mathrm{ml} / \mathrm{minute}$ or no decrease from baseline of $>20 \%$ ), compared with $\mathrm{MMF}$ and corticosteroid treatment ${ }^{83}$. It is prudent to avoid over-immunosuppression in patients treated with triple immunosuppression, as suggested by the higher rate of infective complications in Chinese patients treated with the "multitarget" regimen ${ }^{67}$ and the significant number of infection-related deaths in Asian patients in the AURA-LV trial ${ }^{82}$.

\section{Emerging therapies targeting co-stimulatory pathways}

Co-stimulation in $\mathrm{T}$ lymphocyte activation also plays an important role in autoimmunity. Co-stimulation requires accessory molecules such as CD28/CD80/CD86 and CD40/CD40L. The engagement of CD28 on the cell surface of naïve $T$ cells by CD80 and CD86 present on antigen-presenting cells or B cells activates signaling pathways that promote clonal expansion, $\mathrm{T}$ cell survival, and release of pro-inflammatory cytokines and other mediators of inflammation ${ }^{84}$. Once activated, $\mathrm{T}$ cells express cytotoxic T-lymphocyte-associated protein 4 (CTLA4), a co-stimulatory molecule homologous to $\mathrm{CD} 28$, which has a higher affinity to $\mathrm{CD} 80$ and CD86. CTLA4 serves as a negative regulator of $\mathrm{T}$ and $\mathrm{B}$ cell co-stimulation and terminates $\mathrm{T}$ cell response and cytokine secretion. CTLA4 serves as a master switch for peripheral $\mathrm{T}$ cell tolerance as demonstrated by massive lymphoproliferation and early death in CTLA4knockout mice ${ }^{85}$.

Abatacept (or CTLA4Ig) is a soluble fusion protein comprising the extracellular domain of CTLA4 and a modified fragment of the $\mathrm{Fc}$ domain of human IgG. It is a CTLA4 agonist that interrupts the interaction of CD80/CD86 with CD28 and thus inhibits $\mathrm{T}$ cell co-stimulation, thereby suppressing $\mathrm{T}$ cell activation and $\mathrm{B}$ cell response ${ }^{86}$. Treatment of mice with CTLA4Ig reduced the expansion of $\operatorname{IgG}$ and $\operatorname{IgM}$ autoreactive $B$ cell subsets and $\mathrm{CD}^{+} \mathrm{T}$ cells and suppressed Ig subclass switching, delayed disease onset and anti-dsDNA production, decreased the severity of proteinuria and renal damage, and prolonged survival $^{84}$. Combination treatment with CTLA4Ig and cyclophosphamide was more effective than CTLA4Ig alone in delaying the onset of nephritis in mice and was effective in reducing renal damage in mice with advance renal disease ${ }^{87}$. A phase II clinical trial (NCT00430677) showed that induction therapy with abatacept combined with corticosteroids and MMF improved proteinuria and serological parameters in patients with active proliferative $\mathrm{LN}$ after 12 months but failed to meet the superiority efficacy endpoint (time to complete renal response) ${ }^{88}$. Results from a phase III study (ALLURE; NCT01714817) showed that, in patients with active LN, treatment with abatacept on a background of corticosteroids and MMF for 2 years with a blinded long-term extension improved serological parameters with a more rapid improvement in proteinuria compared with controls who received corticosteroids and MMF with placebo, but the primary endpoint of demonstrating a higher complete remission rate based on clinical parameters in the abatacept group was not achieved ${ }^{89}$. The negative results in both studies have been attributed to the relatively high efficacy of background induction treatment and perhaps over-stringent criteria for treatment response ${ }^{90}$. It has been reported that the podocytes in patients and mice with proteinuric kidney diseases showed increased CD80 expression, which was associated with down-regulation of $\beta 1$ integrin $^{91,92}$. Therefore, apart from interrupting the interaction of CD80/CD86 with CD28, abatacept may stabilize podocyte cytoskeleton and reduce proteinuria through its effect on $\beta 1$-integrin ${ }^{92}$. Whether abatacept may be better suited to treat LN patients with increased CD80 expression in podocytes has not been investigated.

Blockade of the CD40/CD40L pathway presents an alternative therapeutic approach targeting co-stimulatory signals in $\mathrm{T}$ lymphocytes. A phase II clinical trial (NCT02770170) is underway to investigate the efficacy and safety of BI655064 (humanized anti-CD40 monoclonal antibody) in combination with standard-of-care therapy in active LN patients. Another phase II clinical trial (NCT03610516) will test the role of CFZ533 (a humanized anti-CD40 monoclonal antibody) in LN patients who show persistent significant proteinuria after standard induction treatments. Data from a recent phase II study (NCT02804763) demonstrated that dapirolizumab pegol (a pegylated Fab anti-CD40L) treatment in active SLE patients was associated with numerically higher response rates and greater improvement in several clinical outcome measures compared with placebo, but the difference in primary efficacy endpoint of British Isles Lupus Assessment Group-based Composite Lupus Assessment (BICLA) response between the two groups did not reach statistical significance ${ }^{93}$.

\section{Emerging therapies targeting signaling pathways, pro-inflammatory cytokines, complement activation, or neutrophil extracellular traps}

In SLE, multiple signaling pathways and inflammatory mediators are induced by cells of the innate and adaptive immune system and contribute to both systemic and local inflammation. Increases in type I IFN signature, which promotes B cell differentiation and loss of tolerance, and IL-17 and IL-23, which drive tissue injury, are prominent examples ${ }^{94}$.

\section{Mammalian or mechanistic target of rapamycin}

The mammalian or mechanistic target of rapamycin (mTOR) is an evolutionarily conserved serine-threonine kinase that plays a key role in the regulation of cell proliferation, metabolism, and survival. Increased mTOR activation is observed in patients and mice with $\mathrm{LN}^{95}$. Sirolimus is a naturally occurring macrolide antibiotic produced by Streptomyces hygroscopicus and is a specific inhibitor of the mTOR pathway. It is a potent inhibitor of $B$ and $T$ cell proliferation. In pre-nephritic NZB/W F1 mice, treatment with sirolimus suppressed lymphoproliferation, reduced monocyte chemoattractant protein-1 (MCP-1) expression in the kidney, and delayed phenotypic manifestation of disease $^{96}$. Sirolimus treatment given after the onset of nephritis in 
NZB/W F1 mice was effective in decreasing anti-dsDNA level, improving kidney histopathology, and prolonging survival ${ }^{97-99}$. There is also emerging evidence that the anti-proliferative property of mTOR inhibitors extends beyond lymphocytes to non-immune cells. We recently demonstrated that sirolimus decreased mesangial cell proliferation and their binding by anti-dsDNA antibodies and suppressed fibrotic responses in mesangial cells when cells were exposed to anti-dsDNA antibodies or transforming growth factor (TGF)- $\beta 1$, and the effect was mediated through down-regulation of mTOR and extracellular signal-regulated kinase phosphorylation ${ }^{95}$. In NZB/W F1 mice with active nephritis, sirolimus was as effective as mycophenolate in attenuating kidney inflammation and fibrosis $^{95}$. A recent single-arm phase I/II study (NCT00779194) reported that sirolimus treatment in patients with active SLE but without nephritis or life-threatening lupus complications resulted in a decrease in disease activity score and a $\mathrm{T}$ cell profile indicating a less pro-inflammatory phenotype ${ }^{100}$. We have also reported our experience of the use of sirolimus in LN patients, suggesting that this group of drugs may have a role in LN management, especially in patients who do not tolerate other treatments or who could derive benefit from the unique properties of these drugs, such as a lower rate of malignancies ${ }^{101,102}$.

\section{Janus kinase-1, tyrosine kinase-2, and Bruton's tyrosine kinase signaling pathways}

The success of Janus kinase (JAK) inhibition in murine lupus has prompted clinical trials on JAK inhibitors in human SLE. One phase II RCT (NCT02708095) demonstrated the efficacy of baricitinib (a JAK1/2 inhibitor) in alleviating arthritis in SLE patients $^{103}$. A phase IIb study (PF-06700841) will investigate a selective JAK1 inhibitor in moderate-to-severe active SLE patients without renal or cerebral involvement who show an inadequate response to standard therapies. Inhibition of JAK1 should be used with caution, as a phase II clinical trial on solcitinib (a selective JAK1 inhibitor) (NCT01777256) was discontinued because of severe drug reaction with eosinophilia and systemic symptoms (DRESS) syndrome and hepatic function abnormalities $^{104,105}$. Tyrosine kinase 2 (TYK2) is a member of the JAK family and functions downstream of IL-12, IL-23, and type I IFN signaling. A phase II RCT (PAISLEY; NCT03252587) will evaluate the safety and efficacy of BMS-986165, a specific TYK2 inhibitor, in active SLE patients with joint and/or skin involvement ${ }^{106}$, and patients who successfully complete the protocol-required treatment period will be recruited to a subsequent phase II trial that will investigate the long-term safety and efficacy (NCT03920267). Bruton's tyrosine kinase (BTK) is a non-receptor tyrosine kinase expressed in B cells and myeloid cells, and it plays an important role in B cell development, survival, and activation and mediates TLR signaling in macrophages. Inhibition of BTK in lupus-prone mice after disease onset reduced total splenic B cell number and suppressed B cell activation, accompanied by decreased proteinuria and improvement of serological parameters ${ }^{107}$. Treatment of moderate-to-severe active SLE patients without cerebral or renal involvement with the BTK inhibitor fenebrutinib reduced $\mathrm{CD} 19^{+} \mathrm{B}$ cells, anti-dsDNA antibody titer, and
BTK-dependent signature in plasmablasts, but the primary clinical efficacy endpoint (SRI-4) was not met ${ }^{108}$.

\section{Cytokines}

The importance of type I IFN in SLE and LN is well established. Anifrolumab is a monoclonal antibody against type I IFN receptor subunit 1 , and the results from a phase IIb clinical trial (MUSE) showed that anifrolumab treatment significantly suppressed type I IFN gene signatures and lupus disease activity $^{109}$. The results from two subsequent phase III RCTs (TULIP-1 and -2) also showed the clinical benefits of anifrolumab in moderate-to-severe active SLE patients. Although the primary endpoint (SRI-4) was not achieved in TULIP-1, anifrolumab treatment could facilitate corticosteroid reduction and improve disease activity scores such as the CLASI and BICLA scores ${ }^{110}$. The results from TULIP-2 corroborated with TULIP-1: anifrolumab met its primary endpoint (BICLA scores at 52 weeks) in active SLE patients ${ }^{111}$. Consistent with the scientific rationale, the clinical benefit of anifrolumab appears to be more evident in patients with high type I IFN signatures ${ }^{111}$.

Given the pathogenic significance of the IL-17/IL-23 axis in SLE and LN, inhibition of these cytokines may potentially ameliorate SLE and LN. Secukinumab is a fully humanized IgG1 $\kappa$ monoclonal anti-IL-17A antibody and is an approved treatment for active psoriatic arthritis and ankylosing spondylitis, and a phase II clinical trial is underway to investigate its role in patients with refractory LN (NCT04181762). Guselkumab is an anti-IL-23 monoclonal antibody licensed for the treatment of plaque psoriasis, and its use in $\mathrm{LN}$ will be explored in a forthcoming phase II study. IL- 2 regulates $\mathrm{CD}^{+} \mathrm{T}$ cell development and survival, and defective IL-2 production leads to dysregulation in the immune system in SLE patients ${ }^{112,113}$. Previous clinical trials demonstrated that treatment of SLE patients with low-dose IL-2 promoted regulatory $\mathrm{T}$ (Treg) cells and inhibited $\mathrm{T}_{\mathrm{H}} 17$ cells and was associated with the induction of remission ${ }^{114,115}$. One recent RCT showed that low-dose IL-2 treatment (1 million IU subcutaneously every other day for 2 weeks) in active SLE patients did not meet the primary efficacy endpoint of SRI-4 at 12 weeks but achieved higher remission rates than placebo in patients with $\mathrm{LN}$ and was well tolerated $^{116}$. The low-dose IL-2 group also showed expansion of Treg and natural killer cells ${ }^{116}$.

\section{Complement cascade}

The complement cascade plays an essential role in innate immunity and comprises more than 30 circulating proteins. The complement system can be activated through one of three initiation pathways, namely the classical pathway, mannosebinding lectin pathway, and the alternative pathway ${ }^{117}$. The three pathways converge at $\mathrm{C} 3$, resulting in the cleavage of $\mathrm{C} 3$ to the activated components $\mathrm{C} 3 \mathrm{a}$ and $\mathrm{C} 3 \mathrm{~b}$. Dysregulation of complement activation is observed in patients and mice with LN. In LN, deposition of C3-containing immune complexes in the glomeruli initiates tissue injury, whereas deficiencies of some of the components of the classical complement pathway, such as $\mathrm{C} 1 \mathrm{q}$ and $\mathrm{C} 4$, are associated with an increase in the incidence of lupus in humans and also lupus-like disease in $\mathrm{C} 1 \mathrm{q}$ 
or C4 knockout mice ${ }^{118}$. APL-2 (pegcetacoplan) is a small, synthetic cyclic peptide that binds and inhibits $\mathrm{C} 3$ and $\mathrm{C} 3 \mathrm{~b}$ and interferes with the formation of $\mathrm{C} 3$ and $\mathrm{C} 5$ convertases as well as inhibits the activity of pre-formed C3 and C5 convertases ${ }^{119}$. A phase II clinical trial investigated the safety and efficacy of daily APL-2 subcutaneous infusion, administered for 16 weeks with a 6-month safety follow-up, in patients with various glomerulopathies including LN (DISCOVERY; NCT03453619). Preliminary experience from two LN patients recruited into this trial suggests that APL-2 is well-tolerated and treatment was associated with a reduction of proteinuria ${ }^{120}$. Yet the pharmaceutical company has decided to stop the development program for APL-2 in LN after completion of the phase II trial and prefers to focus on other diseases ${ }^{121}$.

Treatment of pre-nephritic NZB/W F1 mice with a monoclonal antibody that inhibits C5 cleavage to the potent proinflammatory and pro-thrombotic molecules C5a and C5b-9 delayed the development of proteinuria, decreased anti-dsDNA antibody level, improved kidney histopathology, and prolonged survival ${ }^{122}$. Eculizumab is a recombinant fully humanized hybrid IgG2/IgG4 monoclonal antibody that directly binds human complement component $\mathrm{C} 5$ and prevents its cleavage to $\mathrm{C} 5 \mathrm{a}$ and C5b-9, thereby blocking terminal complement activation while preserving the functions of early complement components. The success of inhibiting C5 cleavage in murine lupus has prompted a single-dose placebo-controlled phase I study to investigate the safety, pharmacodynamics, and pharmacokinetics of eculizumab in 24 SLE patients. While eculizumab at 4 or $8 \mathrm{mg} / \mathrm{kg}$ was well tolerated and complement level was reduced to baseline level 2 weeks after commencement of the study, clinical parameters were similar to the placebo group. Relatively low baseline disease activity was proposed as a possible reason for the lack of apparent clinical efficacy associated with eculizumab treatment ${ }^{123,124}$. A multicenter phase II clinical trial was designed to investigate the effect of eculizumab in patients with proliferative LN, but the study encountered logistic delays and was terminated ${ }^{125}$. Eculizumab has been approved for the treatment of atypical hemolytic uremic syndrome (aHUS) to inhibit C5-mediated thrombotic microangiopathy ${ }^{126}$. Eculizumab has been reported to be effective in the treatment of a patient with catastrophic antiphospholipid antibody syndrome ${ }^{127}$ and also in a patient with refractory $\mathrm{LN}^{128}$. It has been proposed that eculizumab may be beneficial in the treatment of LN patients who have a thrombotic component analogous to aHUS, evidence of C5-driven glomerular inflammation, or antiphospholipid syndrome, although further studies are warranted. It is noteworthy that inhibition of complement activation at the level of $\mathrm{C} 5$ is associated with Neisseria infection and prophylactic measures may be required ${ }^{118}$.

Dysregulation of the classical complement pathway contributes to the pathogenesis of SLE, and there is emerging evidence to show that the alternative pathway also plays a significant role. The alternative pathway is triggered by the activation of factor B, a trypsin-like serine protease that is the proteolytically active component of $\mathrm{C} 3$ and C5 convertases. Factor B serves as an acute-phase protein and also as a B cell growth factor. Data from 222 Chinese patients with LN showed reduced plasma C1q and C3 levels and increased levels of factor B, C3a, C5a, and soluble $\mathrm{C} 5 \mathrm{~b}-9^{129}$. Plasma factor B level correlated with that of C5a and soluble C5b-9, and factor B colocalized with $\mathrm{C} 3 \mathrm{~b}$ and C5b-9 deposits in the glomeruli ${ }^{129}$. MRL/lpr mice deficient in factor $\mathrm{B}$ showed reduced proteinuria, fewer active serological parameters, and improved kidney histology and vasculitis features compared to wild-type and heterozygous mice $^{130}$. The association between factor $\mathrm{B}$ deficiency and improved disease manifestation may be attributed to decreased C3 activation and/or B cell development. These data suggest that factor B may present a novel therapeutic target in $\mathrm{LN}^{130}$. A highly potent, reversible, and selective small molecule factor B inhibitor (LNP023) is available ${ }^{131,132}$. Oral administration of LNP023 to mice with KRN-induced arthritis reduced overall clinical score and inhibited complement activation and infiltration of immune cells in the joints ${ }^{131}$. In a rodent model of membranous nephropathy, LNP023 administration before disease onset suppressed the development of proteinuria, while treatment after disease onset delayed progression and attenuated glomerulopathy ${ }^{131}$. Phase II clinical studies will investigate the safety, efficacy, tolerability, pharmacokinetics, and pharmacodynamics of LNP023 in patients with paroxysmal nocturnal hemoglobinuria (NCT03439839 and NCT03896152) and IgA nephropathy (NCT03373461).

OMS721 (narsoplimab) is a human monoclonal antibody that targets mannan-binding lectin serine protease 2 (MASP-2), the effector enzyme of the lectin pathway. A phase II study is ongoing to investigate the safety of OMS721 in patients with glomerular diseases including active $\mathrm{LN}$ and will look into its potential steroid-sparing effect (NCT02682407). Preliminary results appear encouraging, with treated patients showing a significant reduction of proteinuria (mean reduction 69\%) and the feasibility for steroid tapering ${ }^{133}$. A phase III study will investigate the effect of OMS721 in LN patients ${ }^{134}$.

\section{Neutrophil extracellular traps}

Neutrophils play a critical role in the innate immune response, and they also regulate the adaptive immune response ${ }^{135}$. Neutrophil cell death, termed NETosis, results in the formation of NETs, which are composed of nuclear components such as DNA and histones decorated with proteins from primary, secondary, and tertiary granules such as myeloperoxidase, neutrophil elastase, pentraxin 3, and matrix metalloproteinase 9. Under physiological conditions, neutrophils release NETs as a defense mechanism to trap and kill microorganisms ${ }^{135}$. NET formation can also be induced by sterile stimuli such as pro-inflammatory cytokines, immune complexes, or autoantibodies ${ }^{135,136}$. In SLE, NET formation is dysregulated and can be induced by ribonucleoprotein antibodies through FcyRIIB (also known as CD32) binding, by the antimicrobial peptide LL37, and by IFN- $\alpha$ produced by plasmacytoid dendritic cells ${ }^{137}$. SLE-induced NETs are believed to be highly immunogenic and contain oxidized mitochondrial DNA, HMGB1, LL37, and immunostimulatory molecules ${ }^{137,138}$. The degradation and clearance of NETs in SLE patients are dependent on DNase 1, but DNase 1 activity is impaired in lupus because of the presence of 
either DNase 1 inhibitors or anti-NET antibodies that inhibit the access of DNase 1 to the NETs, and components of the increased NETs then trigger downstream tissue injury and inflammation ${ }^{135,139,140}$. The inability to degrade NETs is associated with a higher propensity for $\mathrm{LN}^{140}$. In lupus-prone mice, inhibition of NET formation using Cl-amidine (a chemical inhibitor of peptidylarginine deiminase-4) $)^{141}$, DNase $1^{142}$, or FR139317 (a specific endothelin-A receptor antagonist) ${ }^{143}$ resulted in delayed onset of disease, decreased proteinuria, and reduced deposition of immune complexes in the glomeruli as well as down-regulation of IFN-signature inflammatory responses in the bone marrow and kidney ${ }^{141-143}$, suggesting that targeting NETs may be beneficial to lupus patients. Tofacitinib, a JAK/STAT inhibitor, has been shown to reduce NET formation in lupusprone mice, and this was associated with improvements in proteinuria and serological parameters ${ }^{144}$. An ongoing phase I study is investigating the safety of tofacitinib in patients with SLE (NCT02535689). Combination therapy with rituximab and belimumab has also been shown to decrease immune complex-induced NET formation in SLE patients ${ }^{46}$. Metformin has been shown to reduce NET formation in neutrophils stimulated with phorbol 12-myristate 13-acetate and decreased IFN- $\alpha$ secretion in plasmacytoid dendritic cells stimulated with mitochondrial $\mathrm{DNA}^{145}$. Data from a study in Chinese patients (ChiCTR-TRC-12002419) showed that metformin added to conventional treatment for 12 months in SLE patients with mild-to-moderate disease resulted in a decrease in SLE disease activity index (SLEDAI) score by over 50\% $\%^{145}$. Mitochondrial DNA is deposited in NETs in renal biopsy specimens from LN patients, and mitochondrial DNA has been shown to induce higher levels of IFN- $\alpha$ in plasmacytoid dendritic cells compared with anti-dsDNA antibodies. In the MUSE trial, SLE patients with a high type I IFN signature showed higher plasma levels of neutrophil granule constituents such as myeloperoxidase, human neutrophil elastase, and citrullinated histone H3 levels, and treatment with anifrolumab for 1 year resulted in a significant decrease in circulating neutrophil NET complexes compared to the placebo group ${ }^{146}$.

\section{Conclusion and future direction}

As a direct result of greater understanding of disease pathogenesis and key pathways and molecules causing immune activation or organ injury, the development and implementation of novel therapeutic agents for SLE and LN have grown substantially over the past decade. Yet, despite encouraging results from animal studies, relatively few novel therapies have successfully progressed to general clinical usage. Valuable lessons have been learnt from the clinical trials of these novel therapies. Indeed, many of these studies, including those which have apparently failed to achieve their intended aim of demonstrating superiority of the new drug compared with placebo, have provided clinical evidence that substantiate the scientific rationale supporting the clinical relevance of specific pathogenic pathways. Results from these trials, both the positive and the negative ones, have highlighted the heterogeneity in treatment response between different patient subgroups and the caveats and pitfalls in the design of clinical trials, resulting in improved trial design and therapeutic strategies. A challenge in the use of agents that target specific signaling pathways or cytokines is that some of the molecules could serve both pro-inflammatory and anti-inflammatory properties depending on the local cytokine milieu. Given that a multitude of effector mechanisms are activated during active disease, therapies that combine or target multiple pathways may be relevant, although the risk of over-immunosuppression could be a concern. Future trials should also explore ways of incorporating the new treatments to reduce the exposure to established but toxic therapies, especially corticosteroids.

\section{Abbreviations}

aHUS, atypical hemolytic uremic syndrome; APRIL, a proliferating-inducing ligand; BAFF, B cell activating factor; BICLA, British Isles lupus assessment group-based composite lupus assessment; BTK, Bruton's tyrosine kinase; CLASI, cutaneous lupus erythematosus disease area and severity index; CNI, calcineurin inhibitor; CRBN, cereblon; CsA, cyclosporine A; CTLA4; cytotoxic T-lymphocyte-associated protein 4; ds, double-stranded; IFN, interferon; Ig, immunoglobulin; JAK, Janus kinase; IL, interleukin; LOI, loss of improvement; LN, lupus nephritis; MMF, mycophenolate mofetil; mTOR, mammalian or mechanistic target of rapamycin; NETs, neutrophil extracellular traps; NFAT; nuclear factor of activated $\mathrm{T}$ cells; NZB/W F1, New Zealand black and white, first generation; PBMC, peripheral blood mononuclear cell; RCT, randomized controlled trial; SLE, systemic lupus erythematosus; SRI, systemic lupus erythematosus responder index; STAT, signal transducer and activator of transcription; TAC, tacrolimus; TACI, transmembrane activator and cyclophilin ligand interactor; TLR, Tolllike receptor; TNF, tumor necrosis factor; Treg, regulatory $\mathrm{T}$; TYK2, tyrosine kinase-2.

\section{List of clinical studies and their acronyms}

\begin{tabular}{|c|c|}
\hline ALLURE: & $\begin{array}{l}\text { "Efficacy and Safety Study of Abatacept to } \\
\text { Treat Lupus Nephritis" Trial [NCT00430677] }\end{array}$ \\
\hline APRIL-LN: & $\begin{array}{l}\text { "The Efficacy and Safety of Atacicept in } \\
\text { Combination with Mycophenolate Mofetil Used } \\
\text { to Treat Lupus Nephritis" Trial [NCT00573157] }\end{array}$ \\
\hline AURA-LV: & $\begin{array}{l}\text { "Aurinia Urinary Protein Reduction Active - } \\
\text { Lupus with Voclosporin" Trial [NCT02141672] }\end{array}$ \\
\hline AURORA: & $\begin{array}{l}\text { "Aurinia Renal Response in Active Lupus with } \\
\text { Voclosporin" Trial [NCT03021499] }\end{array}$ \\
\hline BLISS-52: & $\begin{array}{l}\text { "A Study of Belimumab in Subjects with } \\
\text { Systemic Lupus Erythematosus (SLE)" Trial } \\
\text { [NCT00424476] }]^{35}\end{array}$ \\
\hline BLISS-76: & $\begin{array}{l}\text { "A Study of Belimumab in Subjects with } \\
\text { Systemic Lupus Erythematosus (SLE)" Trial } \\
{\left[\text { NCT00410384] }{ }^{36}\right.}\end{array}$ \\
\hline BLISS-BELIEVE: & $\begin{array}{l}\text { "A Study to Evaluate the Efficacy and Safety } \\
\text { of Belimumab Administered in Combination } \\
\text { with Rituximab to Adult Subjects with Systemic } \\
\text { Lupus Erythematosus (SLE) - BLISS-BELIEVE" } \\
\text { Trial [NCT03312907] }\end{array}$ \\
\hline BLISS-LN: & $\begin{array}{l}\text { "Efficacy and Safety of Belimumab in Patients } \\
\text { with Active Lupus Nephritis (BLISS-LN)" Trial } \\
\text { [NCT01639339] }{ }^{39}\end{array}$ \\
\hline
\end{tabular}




\begin{tabular}{|l|l|}
\hline CALIBRATE: & $\begin{array}{l}\text { "Rituximab and Belimumab for Lupus } \\
\text { Nephritis" Trial [NCTO2260934] }\end{array}$ \\
\hline ILLUMINATE-1: & $\begin{array}{l}\text { "A Study of LY2127399 in Participants } \\
\text { with Systemic Lupus Erythematosus" Trial } \\
\text { [NCT01205438] }\end{array}$ \\
\hline ILLUMINATE-2: & $\begin{array}{l}\text { "A Study of LY2127399 in Participants } \\
\text { with Systemic Lupus Erythematosus" Trial } \\
\text { [NCT01196091] }\end{array}$ \\
\hline LUNAR: & $\begin{array}{l}\text { "A Study to Evaluate the Efficacy and Safety } \\
\text { of Rituximab in Subjects with International } \\
\text { Society of Nephrolog/Renal Pathology Society } \\
\text { (ISN/RPS) 2003 Class III or IV Lupus Nephritis" } \\
\text { Trial [NCTO0282347] }]^{22}\end{array}$ \\
\hline MISSION: & $\begin{array}{l}\text { "A Study of KZR-616 in Patients with Systemic } \\
\text { Lupus Erythematosus With and Without } \\
\text { Nephritis" Trial [NCTO3393013] }\end{array}$ \\
\hline MUSE: & $\begin{array}{l}\text { "A Study of the Efficacy and Safety of MEDI- } \\
\text { 546 in Systemic Lupus Erythematosus" Trial } \\
\text { [NCT01438489] }\end{array}$ \\
\hline
\end{tabular}

\begin{tabular}{|c|c|}
\hline NOBILITY: & $\begin{array}{l}\text { "A Study to Evaluate the Safety and Efficacy } \\
\text { of Obinutuzumab Compared with Placebo in } \\
\text { Participants with Lupus Nephritis (LN)" Trial } \\
\text { [NCT02550652] }\end{array}$ \\
\hline PAISLEY: & $\begin{array}{l}\text { "An Investigational Study to Evaluate BMS- } \\
986165 \text { in Patients with Systemic Lupus } \\
\text { Erythematosus" Trial [NCT03252587] }\end{array}$ \\
\hline SynBioSe-1: & $\begin{array}{l}\text { "Synergetic B-cell Immunomodulation in SLE" } \\
\text { Trial [NCT02284984] }\end{array}$ \\
\hline SynBioSe-2: & $\begin{array}{l}\text { "Synergetic B-cell Immunomodulation in SLE } \\
-2^{\text {nd }} \text { Study" Trial [NCT03747159] }\end{array}$ \\
\hline TULIP-1: & $\begin{array}{l}\text { "Efficacy and Safety of Anifrolumab Compared } \\
\text { to Placebo in Adult Subjects with Active } \\
\text { Systemic Lupus Erythematosus" Trial } \\
\text { [NCT02446899] }^{110,111}\end{array}$ \\
\hline TULIP-2: & $\begin{array}{l}\text { "Efficacy and Safety of Two Doses of } \\
\text { Anifrolumab Compared to Placebo in } \\
\text { Adult Subjects with Active Systemic Lupus } \\
\text { Erythematosus" Trial [NCT02446912] }\end{array}$ \\
\hline
\end{tabular}

1. Cameron JS: Lupus nephritis. J Am Soc Nephrol. 1999; 10(2): 413-24. PubMed Abstract

2. Mohan C, Putterman C: Genetics and pathogenesis of systemic lupus erythematosus and lupus nephritis. Nat Rev Nephrol. 2015; 11(6): 329-41. PubMed Abstract | Publisher Full Text

3. Chan TM: Treatment of severe lupus nephritis: The new horizon. Nat Rev Nephrol. 2015; 11(1): 46-61.

PubMed Abstract | Publisher Full Text

4. Cooper GS, Dooley MA, Treadwell EL, et al:: Hormonal, environmental, and infectious risk factors for developing systemic lupus erythematosus. Arthritis Rheum. 1998; 41(10): 1714-24. PubMed Abstract | Publisher Full Text

5. Rovin BH, Lu L, Zhang X: A novel interleukin-8 polymorphism is associated with severe systemic lupus erythematosus nephritis. Kidney Int. 2002; 62(1): 261-5.

PubMed Abstract | Publisher Full Text | Faculty Opinions Recommendation

6. Yang $\mathrm{W}, \mathrm{Ng} \mathrm{P}$, Zhao M, et al:: Population differences in SLE susceptibility genes: STAT4 and BLK, but not PXK, are associated with systemic lupus erythematosus in Hong Kong Chinese. Genes Immun. 2009; 10(3): 219-26. PubMed Abstract | Publisher Full Text

7. Jönsen A, Bengtsson AA, Nived O, et al.: Gene-environment interactions in the aetiology of systemic lupus erythematosus. Autoimmunity. 2007; 40(8): 613-7. PubMed Abstract | Publisher Full Text

8. Seredkina N, Zykova SN, Rekvig OP: Progression of Murine Lupus Nephritis Is Linked to Acquired Renal Dnase1 Deficiency and Not to Up-Regulated Apoptosis. Am J Pathol. 2009; 175(1): 97-106.

PubMed Abstract | Publisher Full Text | Free Full Text | Faculty Opinions Recommendation

9. Tiller $\mathrm{T}$, Tsuiji $\mathrm{M}$, Yurasov $\mathrm{S}$, et al:: Autoreactivity in human $\mathbf{I g G}^{+}$memory $\mathbf{B}$ cells. Immunity. 2007; 26(2): 205-13.

PubMed Abstract | Publisher Full Text | Free Full Text

10. Herlands RA, Christensen SR, Sweet RA, et al:: T cell-independent and toll-like receptor-dependent antigen-driven activation of autoreactive B cells. Immunity. 2008; 29(2): 249-60.

PubMed Abstract | Publisher Full Text | Free Full Text

11. Odegard JM, Marks BR, DiPlacido LD, et al:: ICOS-dependent extrafollicular helper T cells elicit IgG production via IL-21 in systemic autoimmunity. $J$ Exp Med. 2008; 205(12): 2873-86.

PubMed Abstract | Publisher Full Text | Free Full Text

12. Tipton CM, Fucile CF, Darce J, et al.: Diversity, cellular origin and autoreactivity of antibody-secreting cell population expansions in acute systemic lupus erythematosus. Nat Immunol. 2015; 16(7): 755-65. PubMed Abstract | Publisher Full Text | Free Full Text Faculty Opinions Recommendation

13. Hoffman W, Lakkis FG, Chalasani G: B Cells, Antibodies, and More. Clin J Am
Soc Nephrol. 2016; 11(1): 137-54.

PubMed Abstract | Publisher Full Text | Free Full Text

14. Avery DT, Bryant VL, Ma CS, et al.: IL-21-Induced Isotype Switching to IgG and IgA by Human Naive B Cells Is Differentially Regulated by IL-4. J Immunol. 2008; 181(3): 1767-79.

PubMed Abstract | Publisher Full Text

15. Vlahakos DV, Foster MH, Adams S, et al:: Anti-DNA antibodies form immune deposits at distinct glomerular and vascular sites. Kidney Int. 1992; 41(6): 1690-700.

PubMed Abstract | Publisher Full Text

16. Tsao BP, Ohnishi $\mathrm{K}$, Cheroutre $\mathrm{H}$, et al:: Failed self-tolerance and autoimmunity in IgG anti-DNA transgenic mice. J Immunol. 1992; 149(1): 350-8. PubMed Abstract

17. Riley JK, Sliwkowski MX: CD20: A gene in search of a function. Semin Oncol. 2000; 27(6 Suppl 12): 17-24.

PubMed Abstract

18. Tsokos GC: B Cells, Be Gone - B-Cell Depletion in the Treatment of Rheumatoid Arthritis. N Engl J Med. 2004; 350(25): 2546-8. PubMed Abstract | Publisher Full Text

19. Cordeiro AC, Isenberg DA: Novel therapies in lupus - focus on nephritis. Acta Reumatol Port. 2008; 33(2): 157-69. PubMed Abstract

20. Edwards JCW, Szczepanski L, Szechinski J, et al.: Efficacy of B-cell-targeted therapy with rituximab in patients with rheumatoid arthritis. $N$ Engl $J$ Med. 2004; 350(25): 2572-81.

PubMed Abstract | Publisher Full Text | Faculty Opinions Recommendation

21. Bekar KW, Owen T, Dunn R, et al:: Prolonged effects of short-term anti-CD20 B cell depletion therapy in murine systemic lupus erythematosus. Arthritis Rheum. 2010; 62(8): 2443-57.

PubMed Abstract | Publisher Full Text | Free Full Text

22. Rovin $\mathrm{BH}$, Furie R, Latinis $\mathrm{K}$, et al.: Efficacy and safety of rituximab in patients with active proliferative lupus nephritis: The Lupus Nephritis Assessment with Rituximab study. Arthritis Rheum. 2012; 64(4): 1215-26. PubMed Abstract | Publisher Full Text | Faculty Opinions Recommendation

23. Tobinai K, Klein C, Oya N, et al.: A Review of Obinutuzumab (GA101), a Novel Type II Anti-CD20 Monoclonal Antibody, for the Treatment of Patients with BCell Malignancies. Adv Ther. 2017; 34(2): 324-56. PubMed Abstract | Publisher Full Text | Free Full Text

24. Freeman CL, Sehn LH: A tale of two antibodies: Obinutuzumab versus rituximab. Br J Haematol. 2018; 182(1): 29-45. PubMed Abstract | Publisher Full Text | Faculty Opinions Recommendation

25. Segerer S, Schlöndorff D: B cells and tertiary lymphoid organs in renal inflammation. Kidney Int. 2008; 73(5): 533-7. PubMed Abstract | Publisher Full Text

26. Elward K, Griffiths M, Mizuno M, et al.: CD46 Plays a Key Role in Tailoring 
Innate Immune Recognition of Apoptotic and Necrotic Cells. J Biol Chem. 2005; 280(43): 36342-54.

PubMed Abstract | Publisher Full Text | Faculty Opinions Recommendation

27. Kawano M, Seya $\mathrm{T}$, Koni I, et al.: Elevated serum levels of soluble membrane cofactor protein (CD46, MCP) in patients with systemic lupus erythematosus (SLE). Clin Exp Immunol. 1999; 116(3): 542-6.

PubMed Abstract | Publisher Full Text | Free Full Text

28. W Weidenbusch M, Römmele C, Schröttle A, et al.: Beyond the LUNAR trial. Efficacy of rituximab in refractory lupus nephritis. Nephrol Dial Transplant. 2013; 28(1): 106-11.

PubMed Abstract | Publisher Full Text | Faculty Opinions Recommendation

29. Díaz-Lagares $C$, Croca $S$, Sangle $S$, et al:: Efficacy of rituximab in 164 patients with biopsy-proven lupus nephritis: Pooled data from European cohorts. Autoimmun Rev. 2012; 11(5): 357-64. PubMed Abstract | Publisher Full Tex

30. Moroni G, Gallelli B, Sinico RA, et al:: Rituximab versus oral cyclophosphamide for treatment of relapses of proliferative lupus nephritis: A clinical observational study. Ann Rheum Dis. 2012. 71(10): 1751-2. PubMed Abstract | Publisher Full Text

31. C Condon MB, Ashby D, Pepper RJ, et al.: Prospective observational singlecentre cohort study to evaluate the effectiveness of treating lupus nephritis with rituximab and mycophenolate mofetil but no oral steroids. Ann Rheum Dis. 2013; 72(8): 1280-6.

PubMed Abstract | Publisher Full Text | Faculty Opinions Recommendation

32. Pepper R, Griffith M, Kirwan C, et al: Rituximab is an effective treatment for lupus nephritis and allows a reduction in maintenance steroids. Nephrol Dial Transplant. 2009; 24(12): 3717-23.

PubMed Abstract | Publisher Full Text

33. Furie R, Aroca G, Alvarez A, et al:: A phase II randomized, double-blind, placebo-controlled study to evaluate the efficacy and safety of obinutuzumab or placebo in combination with mycophenolate mofetil in patients with active class III or IV lupus nephritis. Arthritis Rheumatol. 2019; 71: [Abstract]. Reference Source

34. Rovin B, Furie R, Aroca G, et al: B-cell depletion and response in a randomized, controlled trial of obinutuzumab for proliferative lupus nephritis. Kidney Int Rep. 2020; 5(3): S352 [Abstract]. Reference Source

35. Navarra SV, Guzmán RM, Gallacher AE, et al:: Efficacy and safety of belimumab in patients with active systemic lupus erythematosus: $\mathbf{A}$ randomised, placebo-controlled, phase 3 trial. Lancet. 2011; 377(9767): 721-31. PubMed Abstract | Publisher Full Text | Faculty Opinions Recommendation

36. CFurie R, Petri M, Zamani O, et al.: A phase III, randomized, placebocontrolled study of belimumab, a monoclonal antibody that inhibits $B$ lymphocyte stimulator, in patients with systemic lupus erythematosus. Arthritis Rheum. 2011; 63(12): 3918-30.

PubMed Abstract | Publisher Full Text | Free Full Text |

Faculty Opinions Recommendation

37. Dooley MA, Houssiau F, Aranow C, et al.: Effect of belimumab treatment on renal outcomes: Results from the phase 3 belimumab clinical trials in patients with SLE. Lupus. 2012; 22(1): 63-72.

PubMed Abstract | Publisher Full Text

38. Stohl W, Hiepe F, Latinis KM, et al:: Belimumab reduces autoantibodies, normalizes low complement levels, and reduces select $B$ cell populations in patients with systemic lupus erythematosus. Arthritis Rheum. 2012; 64(7): 2328-37. PubMed Abstract | Publisher Full Text | Free Full Text

39. GSK announces positive headline results in phase 3 study of Benlysta in patients with lupus nephritis. 2019.

Reference Source

40. Isenberg DA, Petri M, Kalunian K, et al:: Efficacy and safety of subcutaneous tabalumab in patients with systemic lupus erythematosus: Results from ILLUMINATE-1, a 52-week, phase III, multicentre, randomised, double-blind, placebo-controlled study. Ann Rheum Dis. 2016; 75(2): 323-31. PubMed Abstract | Publisher Full Text | Faculty Opinions Recommendation

41. Merrill JT, van Vollenhoven RF, Buyon JP, et al:: Efficacy and safety of subcutaneous tabalumab, a monoclonal antibody to B-cell activating factor, in patients with systemic lupus erythematosus: Results from ILLUMINATE-2, a 52-week, phase III, multicentre, randomised, double-blind, placebo-controlled study. Ann Rheum Dis. 2016; 75(2): 332-40.

PubMed Abstract | Publisher Full Text | Faculty Opinions Recommendation

42. Rovin BH, Dooley MA, Radhakrishnan J, et al.: The impact of tabalumab on the kidney in systemic lupus erythematosus: Results from two phase 3 randomized, clinical trials. Lupus. 2016; 25(14): 1597-601. PubMed Abstract | Publisher Full Text

43. Ginzler EM, Wax S, Rajeswaran A, et al:: Atacicept in combination with MM and corticosteroids in lupus nephritis: Results of a prematurely terminated trial. Arthritis Res Ther. 2012; 14(1): R33.

PubMed Abstract | Publisher Full Text | Free Full Text |

Faculty Opinions Recommendation

44. Wu D, Li J, Xu D, et al:: A human recombinant fusion protein targeting $\mathbf{B}$ lymphocyte stimulator (BlyS) and a proliferation-Inducing ligand (APRIL), telitacicept (RC18), in systemic lupus erythematosus (SLE): results of a phase 2b study. Arthritis Rheumatol. 2019; 71 [Abstract].

Reference Source
45. Dall'Era M, Aranow C, Byron M, et al.: Phase 2 trial of induction therapy with anti-CD20 (RITUXIMAB) followed by maintenance therapy with anti-BAFF (BELIMUMAB) in patients with active lupus nephritis. Ann Rheum Dis. 2018; 77 : 690 [Abstract] Reference Source

46. Kraaij T, Kamerling SWA, de Rooij ENM, et al.: The NET-effect of combining rituximab with belimumab in severe systemic lupus erythematosus. $J$ Autoimmun. 2018; 91: 45-54.

PubMed Abstract | Publisher Full Text | Faculty Opinions Recommendation

47. Teng YKO, Bruce IN, Diamond B, et al.: Phase III, multicentre, randomised, double-blind, placebo-controlled, 104-week study of subcutaneous belimumab administered in combination with rituximab in adults with systemic lupus erythematosus (SLE): BLISS-BELIEVE study protocol. BMJ Open. 2019; 9(3): e025687.

PubMed Abstract | Publisher Full Text | Free Full Text

48. Merrill J, June J, Koumpouras F, et al:: Phase 2, double-blind, randomized, placebo-controlled study of a reversible $B$ cell inhibitor, XmAb5871, in systemic lupus erythematosus (SLE). Ann Rheum Dis. 2019; 78: 761-62. Publisher Full Text

49. Alexander T, Sarfert R, Klotsche J, et al:: The proteasome inhibitior bortezomib depletes plasma cells and ameliorates clinical manifestations of refractory systemic lupus erythematosus. Ann Rheum Dis. 2015; 74(7): 1474-8. PubMed Abstract | Publisher Full Text | Free Full Text

50. Zhang H, Liu Z, Huang L, et al:: The short-term efficacy of bortezomib combined with glucocorticoids for the treatment of refractory lupus nephritis. Lupus. 2017; 26(9): 952-8.

PubMed Abstract | Publisher Full Text

51. Furie R, Bomba D, Dall'era M, et al.: Treatment of systemic lupus erythematosus patients with the immunoproteasome inhibitor KZR-616: results from the first 2 cohorts of an open-label phase 1b dose escalation trial. Ann Rheum Dis. 2019; 78: 776-77 [Abstract].

Publisher Full Text

52. Georgopoulos K, Winandy S, Avitahl N: The role of the Ikaros gene in lymphocyte development and homeostasis. Annu Rev Immunol. 1997; 15: 155-76. PubMed Abstract | Publisher Full Text

53. John LB, Ward AC: The lkaros gene family: Transcriptional regulators of hematopoiesis and immunity. Mol Immunol. 2011; 48(9-10): 1272-8. PubMed Abstract | Publisher Full Text

54. Hu SJ, Wen LI, Hu X, et al.: IKZF1: A critical role in the pathogenesis of systemic lupus erythematosus? Mod Rheumatol. 2013; 23(2): 205-9. PubMed Abstract | Publisher Full Text

55. Wang JH, Avitahl N, Cariappa A, et al:: Aiolos Regulates B Cell Activation and Maturation to Effector State. Immunity. 1998; 9(4): 543-53.

PubMed Abstract | Publisher Full Text

56. Nakayama $\mathrm{Y}, \mathrm{Kosek} \mathrm{J}$, Capone L, et al:: Aiolos Overexpression in Systemic Lupus Erythematosus B Cell Subtypes and BAFF-Induced Memory B Cell Differentiation Are Reduced by CC-220 Modulation of Cereblon Activity. $J$ Immunol. 2017; 199(7): 2388-407. PubMed Abstract | Publisher Full Text | Free Full Text

57. Schafer $\mathrm{PH}, \mathrm{Ye} \mathrm{Y}, \mathrm{Wu} \mathrm{L}$, et al:: Cereblon modulator iberdomide induces degradation of the transcription factors Ikaros and Aiolos: Immunomodulation in healthy volunteers and relevance to systemic lupus erythematosus. Ann Rheum Dis. 2018; 77(10): 1516-23.

PubMed Abstract | Publisher Full Text | Free Full Text | Faculty Opinions Recommendation

58. Furie R, Werth VP, Gaudy A, et al:: A randomized, placebo-controlled, double-blind, ascending-dose, safety, and pharmacokinetics study of CC-220 in subjects with systemic lupus erythematosus. Arthritis Rheumatol. 2017; 69 [Abstract]. Reference Source

59. Werth VP, Furie R, Gaudy A, et al: CC-220 decreases B-cell subsets and plasmacytoid dendritic cells in systemic lupus erythematosus (SLE) patients and is associated with skin improvement: pharmacodynamic results from a phase lla proof of concept study. Arthritis Rheumatol. 2017; 69 [Abstract]. Reference Source

60. Mak A, Kow NY: The pathology of T cells in systemic lupus erythematosus. $J$ Immunol Res. 2014; 2014: 419029. PubMed Abstract | Publisher Full Text | Free Full Text

61. Dutta D, Barr VA, Akpan I, et al.: Recruitment of calcineurin to the TCR positively regulates T cell activation. Nat Immunol. 2017; 18(2): 196-204. PubMed Abstract | Publisher Full Text | Free Full Text

62. Ekberg H, van Gelder T, Kaplan B, et al:: Relationship of tacrolimus exposure and mycophenolate mofetil dose with renal function after renal transplantation. Transplantation. 2011; 92(1): 82-7. PubMed Abstract | Publisher Full Text

63. N Fu J, Wang Z, Lee $\mathrm{K}$, et al.: Transcriptomic analysis uncovers nove synergistic mechanisms in combination therapy for lupus nephritis. Kidney Int 2018; 93(2): 416-29. PubMed Abstract | Publisher Full Text | Faculty Opinions Recommendation

64. Faul C, Donnelly M, Merscher-Gomez S, et al:: The actin cytoskeleton of kidney podocytes is a direct target of the antiproteinuric effect of cyclosporine A. Nat Med. 2008; 14(9): 931-8.

PubMed Abstract | Publisher Full Text | Free Full Text |

Faculty Opinions Recommendation 
65. Coward RJM, Foster RR, Patton D, et al:: Nephrotic Plasma Alters Slit Diaphragm-Dependent Signaling and Translocates Nephrin, Podocin, and CD2 Associated Protein in Cultured Human Podocytes. J Am Soc Nephrol. 2005; 16(3): 629-37.

PubMed Abstract | Publisher Full Text

66. Chen W, Tang X, Liu Q, et al:: Short-term outcomes of induction therapy with tacrolimus versus cyclophosphamide for active lupus nephritis: A multicenter randomized clinical trial. Am J Kidney Dis. 2011; 57(2): 235-44. PubMed Abstract | Publisher Full Text

67. Liu Z, Zhang H, Liu Z, et al.: Multitarget Therapy for Induction Treatment of Lupus Nephritis: A Randomized Trial. Ann Intern Med. 2015; 162(1): 18-26. PubMed Abstract | Publisher Full Text

68. Mok CC, Ying KY, Yim CW, et al:: Tacrolimus versus mycophenolate mofetil for induction therapy of lupus nephritis: A randomised controlled trial and longterm follow-up. Ann Rheum Dis. 2016; 75(1): 30-6.

PubMed Abstract | Publisher Full Text

69. Zhang H, Liu Z, Zhou M, et al:: Multitarget Therapy for Maintenance Treatment of Lupus Nephritis. J Am Soc Nephrol. 2017; 28(12): 3671-8. PubMed Abstract | Publisher Full Text | Free Full Text

70. Choi CB, Won S, Bae SC: Outcomes of multitarget therapy using mycophenolate mofetil and tacrolimus for refractory or relapsing lupus nephritis. Lupus. 2018; 27(6): 1007-11.

PubMed Abstract | Publisher Full Text | Faculty Opinions Recommendation

71. P Park DJ, Kang JH, Lee KE, et al:: Efficacy and safety of mycophenolate mofetil and tacrolimus combination therapy in patients with lupus nephritis: A nationwide multicentre study. Clin Exp Rheumatol. 2019; 37(1): 89-96. PubMed Abstract | Faculty Opinions Recommendation

72. Tanaka H, Watanabe S, Aizawa-Yashiro T, et al:: Long-Term Tacrolimus-Based Immunosuppressive Treatment for Young Patients with Lupus Nephritis: A Prospective Study in Daily Clinical Practice. Nephron Clin Pract. 2013; 121(3-4): c165-c173.

PubMed Abstract | Publisher Full Text

73. Kise T, Yoshimura H, Fukuyama S, et al.: Successful treatment with mycophenolate mofetil and tacrolimus in juvenile severe lupus nephritis. Case Rep Pediatr. 2015; 2015: 651803.

PubMed Abstract | Publisher Full Text | Free Full Text

74. Dall'Era M, Cisternas MG, Smilek DE, et al:: Predictors of Long-Term Rena Outcome in Lupus Nephritis Trials: Lessons Learned from the Euro-Lupus Nephritis Cohort. Arthritis Rheumatol. 2015; 67(5): 1305-13.

PubMed Abstract | Publisher Full Text

75. Chan TM: Preventing renal failure in patients with severe lupus nephritis. Kidney Int Suppl. 2005; (94): S116-9.

PubMed Abstract | Publisher Full Tex

76. Yap DYH, Ma MKM, Mok MMY, et al.: Long-term data on tacrolimus treatment in lupus nephritis. Rheumatology (Oxford). 2014; 53(12): 2232-7. PubMed Abstract | Publisher Full Text

77. Praga M, Barrio V, Juárez GF, et al.: Tacrolimus monotherapy in membranous nephropathy: A randomized controlled trial. Kidney Int. 2007; 71(9): 924-30. PubMed Abstract | Publisher Full Text

78. Austin HA, Illei GG, Braun MJ, et al:: Randomized, Controlled Trial of Prednisone, Cyclophosphamide, and Cyclosporine in Lupus Membranous Nephropathy. J Am Soc Nephrol. 2009; 20(4): 901-11. PubMed Abstract | Publisher Full Text | Free Full Text Faculty Opinions Recommendation

79. Mok CC: Calcineurin inhibitors in systemic lupus erythematosus. Best Pract Res Clin Rheumatol. 2017; 31(3): 429-38. PubMed Abstract | Publisher Full Text

80. Sin FE, Isenberg D: An evaluation of voclosporin for the treatment of lupus nephritis. Expert Opin Pharmacother. 2018; 19(14): 1613-21. PubMed Abstract | Publisher Full Text | Faculty Opinions Recommendation

81. D Dörner T, Furie R: Novel paradigms in systemic lupus erythematosus. Lancet. 2019; 393(10188): 2344-58. PubMed Abstract | Publisher Full Text | Faculty Opinions Recommendation

82. R Rovin BH, Solomons N, Pendergraft WF, et al:: A randomized, controlled double-blind study comparing the efficacy and safety of dose-ranging voclosporin with placebo in achieving remission in patients with active lupus nephritis. Kidney Int. 2019; 95(1): 219-31.

PubMed Abstract | Publisher Full Text | Faculty Opinions Recommendation

83. Gibson KL, Parikh S, Saxena A, et al.: AURORA phase 3 trial demonstrates voclosporin statistical superiority over standard of care in lupus nephritis (LN). Am J Kidney Dis. 2020; 75(5): 819 [Abstract] Reference Source

84. Mihara M, Tan I, Chuzhin Y, et al:: CTLA4Ig inhibits T cell-dependent B-cell maturation in murine systemic lupus erythematosus. J Clin Invest. 2000; 106(1): 91-101.

PubMed Abstract | Publisher Full Text | Free Full Text

85. Waterhouse P, Penninger JM, Timms E, et al.: Lymphoproliferative Disorders with Early Lethality in Mice Deficient in Ctla-4. Science. 1995; 270(5238): 985-8. PubMed Abstract | Publisher Full Text

86. Dall'Era M, Davis J: CTLA4Ig: A novel inhibitor of costimulation. Lupus. 2004 13(5): 372-6.

PubMed Abstract | Publisher Full Text
87. Daikh DI, Wofsy D: Cutting Edge: Reversal of Murine Lupus Nephritis with CTLA4Ig and Cyclophosphamide. J Immunol. 2001; 166(5): 2913-6.

PubMed Abstract | Publisher Full Text

88. Furie R, Nicholls K, Cheng TT, et al.: Efficacy and safety of abatacept in lupus nephritis: A twelve-month, randomized, double-blind study. Arthritis Rheumatol. 2014; 66(2): 379-89.

PubMed Abstract | Publisher Full Text

89. Furie R, Dooley MA, Wofsy $\mathrm{D}$, et al:: A phase III randomised, double-blind, placebo-controlled study to evaluate the efficacy and safety of abatacept or placebo on standard of care in patients with active class III or IV lupus nephritis. Ann Rheum Dis. 2020; 77 : 176 [Abstract]

Reference Source

90. Wofsy D, Hillson JL, Diamond B: Abatacept for lupus nephritis: Alternative definitions of complete response support conflicting conclusions. Arthritis Rheum. 2012; 64(11): 3660-5.

PubMed Abstract | Publisher Full Text | Faculty Opinions Recommendation

91. Y Yu CC, Fornoni A, Weins A, et al:: Abatacept in B7-1-positive proteinuric kidney disease. N Engl J Med. 2013; 369(25): 2416-23. PubMed Abstract | Publisher Full Text | Free Full Text | Faculty Opinions Recommendation

92. Reiser J, von Gersdorff G, Loos M, et al.: Induction of B7-1 in podocytes is associated with nephrotic syndrome. J Clin Invest. 2004; 113(10): 1390-7. PubMed Abstract | Publisher Full Text | Free Full Text | Faculty Opinions Recommendation

93. Furie R, Bruce I, Dorner T, et al.: Efficacy and safety of dapirolizumab pegol (DZP) in patients with moderately to severely active systemic lupus erythematosus (SLE): A randomized, placebo (PBO)-controlled study. Ann Rheum Dis. 2019; 78: 775-76. Reference Source

94. Koga T, Ichinose K, Kawakami A, et al:: The role of IL-17 in systemic lupus erythematosus and its potential as a therapeutic target. Expert Rev Clin Immunol. 2019; 15(6): 629-37.

PubMed Abstract | Publisher Full Text | Faculty Opinions Recommendation

95. Zhang C, Chan CCY, Cheung KF, et al.: Effect of mycophenolate and rapamycin on renal fibrosis in lupus nephritis. Clin Sci (Lond). 2019; 133(15): 1721-44. PubMed Abstract | Publisher Full Text

96. Lui SL, Yung S, Tsang R, et al:: Rapamycin prevents the development of nephritis in lupus-prone NZB/W F mice. Lupus. 2008; 17(4): 305-13. PubMed Abstract | Publisher Full Text

97. Stylianou K, Petrakis I, Mavroeidi V, et al.: The PI3K/Akt/mTOR pathway is activated in murine lupus nephritis and downregulated by rapamycin. Nephrol Dial Transplant. 2011; 26(2): 498-508. PubMed Abstract | Publisher Full Text

98. Alperovich G, Rama I, Lloberas N, et al:: New immunosuppresor strategies in the treatment of murine lupus nephritis. Lupus. 2007; 16(1): 18-24. PubMed Abstract | Publisher Full Text

99. Lui SL, Tsang R, Chan KW, et al:: Rapamycin attenuates the severity of established nephritis in lupus-prone NZB/W $\mathrm{F}_{1}$ mice. Nephrol Dial Transplant. 2008; 23(9): 2768-76.

PubMed Abstract | Publisher Full Text

100. Lai ZW, Kelly R, Winans T, et al.: Sirolimus in patients with clinically active systemic lupus erythematosus resistant to, or intolerant of, conventional medications: A single-arm, open-label, phase 1/2 trial. Lancet. 2018; 391(10126): 1186-96.

PubMed Abstract | Publisher Full Text | Free Full Text | Faculty Opinions Recommendation

101. Yap DYH, Ma MKM, Tang CS, et al:: Proliferation signal inhibitors in the treatment of lupus nephritis: Preliminary experience. Nephrology (Carlton). 2012; 17(8): 676-80. PubMed Abstract | Publisher Full Text

102. Yap DYH, Tang C, Chan GCW, et al.: Longterm Data on Sirolimus Treatment in Patients with Lupus Nephritis. J Rheumatol. 2018; 45(12): 1663-70. PubMed Abstract | Publisher Full Text

103. W Wallace DJ, Furie RA, Tanaka Y, et al:: Baricitinib for systemic lupus erythematosus: A double-blind, randomised, placebo-controlled, phase 2 trial. Lancet 2018; 392(10143): 222-31.

PubMed Abstract | Publisher Full Text | Faculty Opinions Recommendation

104. Kahl L, Patel J, Layton M, et al.: Safety, tolerability, efficacy and pharmacodynamics of the selective JAK1 inhibitor GSK2586184 in patients with systemic lupus erythematosus. Lupus. 2016; 25(13): 1420-30. PubMed Abstract | Publisher Full Text

105. van Vollenhoven RF, Layton M, Kahl L, et al:: DRESS syndrome and reversible liver function abnormalities in patients with systemic lupus erythematosus treated with the highly selective JAK-1 inhibitor GSK2586184. Lupus. 2015; 24(6): 648-9.

PubMed Abstract | Publisher Full Text

106. Singhal S, Shah V, Crater C, et al.: Oral selective tyrosine kinase 2 (TYK2) inhibition with BMS-986165 in patients with systemic lupus erythematosus: a phase 2, randomized, double-blind, placebo-controlled study (PAISLEY). Lupus Sci Med. 2019; 6(Suppl 1): A5-A6 [Abstract]. Publisher Full Text

107. Chalmers SA, Glynn E, Garcia SJ, et al:: BTK inhibition ameliorates kidney 
disease in spontaneous lupus nephritis. Clin Immunol. 2018; 197: 205-18. PubMed Abstract | Publisher Full Text | Free Full Text | Faculty Opinions Recommendation

108. Isenberg D, Furie R, Jones N, et al.: Efficacy, safety, and pharmacodynamic effects of the Bruton's tyrosine kinase inhibitor, fenebrutinib (GDC-0853), in moderate to severe systemic lupus erythematosus: results of a phase 2 randomized controlled trial. Arthritis Rheumatol. 2019; 71(suppl 10): [Abstract] Reference Source

109. A Furie R, Khamashta M, Merrill JT, et al: Anifrolumab, an Anti-Interferon$\alpha$ Receptor Monoclonal Antibody, in Moderate-to-Severe Systemic Lupus Erythematosus. Arthritis Rheumatol. 2017; 69(2): 376-86. PubMed Abstract | Publisher Full Text | Free Full Text | Faculty Opinions Recommendation

110. C Furie RA, Morand EF, Bruce IN, et al:: Type I interferon inhibitor anifroluma in active systemic lupus erythematosus (TULIP-1): A randomised, controlled, phase 3 trial. Lancet Rheumatol. 2019; 1(4): e208-e219. Publisher Full Text | Faculty Opinions Recommendation

111. Morand EF, Furie R, Tanaka Y, et al.: Trial of Anifrolumab in Active Systemic Lupus Erythematosus. N Engl J Med. 2020; 382(3): 211-21. PubMed Abstract | Publisher Full Text | Faculty Opinions Recommendation

112. Humrich JY, Morbach H, Undeutsch R, et al.: Homeostatic imbalance of regulatory and effector T cells due to IL-2 deprivation amplifies murine lupus. Proc Natl Acad Sci U S A. 2010; 107(1): 204-9. PubMed Abstract | Publisher Full Text | Free Full Text

113. Humrich JY, Riemekasten G: Low-dose IL-2 therapy - a complex scenario that remains to be further explored. Nat Rev Rheumatol. 2017; 13(6): 386. PubMed Abstract | Publisher Full Text

114. $\mathrm{He}$ J, Zhang X, Wei Y, et al:: Low-dose interleukin-2 treatment selectively modulates $\mathrm{CD}^{+} \mathrm{T}$ cell subsets in patients with systemic lupus erythematosus. Nat Med. 2016; 22(9): 991-3.

PubMed Abstract | Publisher Full Text | Faculty Opinions Recommendation

115. von Spee-Mayer C, Siegert E, Abdirama D, et al.: Low-dose interleukin-2 selectively corrects regulatory $\mathrm{T}$ cell defects in patients with systemic lupus erythematosus. Ann Rheum Dis. 2016; 75(7): 1407-15. PubMed Abstract | Publisher Full Text

116. He J, Zhang R, Shao M, et al:: Efficacy and safety of low-dose IL-2 in the treatment of systemic lupus erythematosus: A randomised, double-blind, placebo-controlled trial. Ann Rheum Dis. 2019; 79(1): 141-9. PubMed Abstract | Publisher Full Text | Free Full Text | Faculty Opinions Recommendation

117. Thurman JM, Nester CM: All Things Complement. Clin J Am Soc Nephrol. 2016; 11(10): 1856-66.

PubMed Abstract | Publisher Full Text | Free Full Text

118. Trouw LA, Pickering MC, Blom AM: The complement system as a potential therapeutic target in rheumatic disease. Nat Rev Rheumatol. 2017; 13(9): 538-47. PubMed Abstract | Publisher Full Text

119. Simon-Tillaux N, Chauvet S, El mehdi D, et al.: APL-2 prevents both C3 and C5 convertase formation and activity: a potential therapeutic for renal diseases. J Am Soc Nephrol. 2019; 30: 918 [Abstract].

120. Dixon BP, Greenbaum LA, Huang L, et al:: C3 inhibition with APL-2 targets the underlying disease process of $C 3 G$ complement hyperactivity and improves proteinuria. J Am Soc Nephrol. 2019; 30: 676 [Abstract].

121. Apellis stopping development of APL-2 for lupus nephritis after completion of phase 2 trial. 2019 Reference Source

122. Wang $\mathrm{Y}, \mathrm{Hu} \mathrm{Q}$, Madri JA, et al.: Amelioration of lupus-like autoimmune disease in NZB/WF1 mice after treatment with a blocking monoclonal antibody specific for complement component C5. Proc Natl Acad Sci U S A. 1996; 93(16): 8563-8. PubMed Abstract | Publisher Full Text | Free Full Text

123. Sciascia S, Radin M, Yazdany J, et al.: Expanding the therapeutic options for renal involvement in lupus: Eculizumab, available evidence. Rheumatol Int. 2017; 37(8): 1249-55.

PubMed Abstract | Publisher Full Text

124. Furie $\mathrm{R}$, Matis $\mathrm{L}$, Rollins $\mathrm{SA}$, et al:: A single dose, placebo controlled, double blind, phase I study of the humanized anti-C5 antibody h5G1.1 in patients with systemic lupus erythematosus. Arthritis Rheum. 2004; 50: [Abstract].

125. Bao L, Cunningham PN, Quigg RJ: Complement in Lupus Nephritis: New Perspectives. Kidney Dis (Basel). 2015; 1(2): 91-9. PubMed Abstract | Publisher Full Text | Free Full Text

126. Zuber J, Fakhouri F, Roumenina LT, et al.: Use of eculizumab for atypical haemolytic uraemic syndrome and C3 glomerulopathies. Nat Rev Nephrol. 2012; 8(11): 643-57.

PubMed Abstract | Publisher Full Text | Faculty Opinions Recommendation

127. Strakhan M, Hurtado-Sbordoni M, Galeas N, et al.: $\mathbf{3 6}$-year-old female with catastrophic antiphospholipid syndrome treated with eculizumab: A case report and review of literature. Case Rep Hematol. 2014; 2014: 704371. PubMed Abstract | Publisher Full Text | Free Full Text
128. Pickering MC, Ismajli M, Condon MB, et al.: Eculizumab as Rescue Therapy in Severe Resistant Lupus Nephritis. Rheumatology (Oxford). 2015; 54(12): 2286-8.

PubMed Abstract | Publisher Full Text | Free Full Text

129. Song D, Guo WY, Wang FM, et al:: Complement Alternative Pathway's Activation in Patients With Lupus Nephritis. Am J Med Sci. 2017; 353(3): 247-57.

PubMed Abstract | Publisher Full Text

130. Watanabe H, Garnier G, Circolo A, et al:: Modulation of Renal Disease in MRL/lpr Mice Genetically Deficient in the Alternative Complement Pathway Factor B. $J$ Immunol. 2000; 164(2): 786-94. PubMed Abstract | Publisher Full Text

131. S Schubart A, Anderson K, Mainolfi N, et al.: Small-molecule factor B inhibitor or the treatment of complement-mediated diseases. Proc Natl Acad Sci U S A. 2019; 116(16): 7926-31.

PubMed Abstract | Publisher Full Text | Free Full Text | Faculty Opinions Recommendation

132. Mainolfi N, Ehara T, Karki RG, et al.: Discovery of 4-((2 S,4 S)-4-Ethoxy-1-((5methoxy-7-methyl-1 $\mathrm{H}$-indol-4-yl)methyl)piperidin-2-yl)benzoic Acid (LNP023) a Factor B Inhibitor Specifically Designed To Be Applicable to Treating a Diverse Array of Complement Mediated Diseases. J Med Chem. 2020; 63(11): 5697-722.

PubMed Abstract | Publisher Full Text | Faculty Opinions Recommendation

133. Omeros reports more positive data in OMS721 phase 2 trial in renal diseases. 2017.

Reference Source

134. Complement-mediated disease: Lupus nephritis. 2020. Reference Source

135. Mantovani A, Cassatella MA, Costantini C, et al:: Neutrophils in the activation and regulation of innate and adaptive immunity. Nat Rev Immunol. 2011; 11(5): 519-31.

PubMed Abstract | Publisher Full Text

136. Brinkmann V, Zychlinsky A: Neutrophil extracellular traps: Is immunity the second function of chromatin? J Cell Biol. 2012; 198(5): 773-83. PubMed Abstract | Publisher Full Text | Free Full Text

137. Garcia-Romo GS, Caielli S, Vega B, et al:: Netting neutrophils are major inducers of type I IFN production in pediatric systemic lupus erythematosus. Sci Transl Med. 2011; 3(73): 73ra20.

PubMed Abstract | Publisher Full Text | Free Full Text | Faculty Opinions Recommendation

138. Lood C, Blanco LP, Purmalek MM, et al.: Neutrophil extracellular traps enriched in oxidized mitochondrial DNA are interferogenic and contribute to lupus-like disease. Nat Med. 2016; 22(2): 146-53. PubMed Abstract | Publisher Full Text | Free Full Text | Faculty Opinions Recommendation

139. Jeannin $P$, Jaillon $S$, Delneste $Y$ : Pattern recognition receptors in the immune response against dying cells. Curr Opin Immunol. 2008; 20(5): 530-7. PubMed Abstract | Publisher Full Text

140. Hakkim A, Fürnrohr BG, Amann K, et al:: Impairment of neutrophil extracellular trap degradation is associated with lupus nephritis. Proc Natl Acad Sci U S A. 2010; 107(21): 9813-8. PubMed Abstract | Publisher Full Text | Free Full Text | Faculty Opinions Recommendation

141. Knight JS, Subramanian V, O'Dell AA, et al:: Peptidylarginine deiminase inhibition disrupts NET formation and protects against kidney, skin and vascular disease in lupus-prone MRL/Ipr mice. Ann Rheum Dis. 2015; 74(12): 2199-206.

PubMed Abstract | Publisher Full Text | Free Full Text

142. Macanovic M, Sinicropi $D$, Shak $S$, et al:: The treatment of systemic lupus erythematosus (SLE) in NZB/W F, hybrid mice; studies with recombinan murine DNase and with dexamethasone. Clin Exp Immunol. 1996; 106(2): 243-52.

PubMed Abstract | Publisher Full Text | Free Full Text

143. Nakamura T, Ebihara I, Tomino Y, et al.: Effect of a specific endothelin A receptor antagonist on murine lupus nephritis. Kidney Int. 1995; 47(2): 481-9. PubMed Abstract | Publisher Full Text

144. Furumoto Y, Smith CK, Blanco L, et al.: Tofacitinib Ameliorates Murine Lupus and Its Associated Vascular Dysfunction. Arthritis Rheumatol. 2017; 69(1): 148-60. PubMed Abstract | Publisher Full Text | Free Full Text

145. N Wang H, Li T, Chen S, et al.: Neutrophil Extracellular Trap Mitochondrial DNA and Its Autoantibody in Systemic Lupus Erythematosus and a Proof-ofConcept Trial of Metformin. Arthritis Rheumatol. 2015; 67(12): 3190-200. PubMed Abstract | Publisher Full Text | Faculty Opinions Recommendation

146. White WI, Seto NL, Playford MP, et al:: Alteration of mediators of vascular inflammation by anifrolumab in the phase iib muse study in sle. Ann Rheum Dis. 2018; 77(Suppl 2): 136-37. [Abstract].

Publisher Full Text 


\section{Open Peer Review}

\section{Current Peer Review Status:}

\section{Editorial Note on the Review Process}

Faculty Reviews are review articles written by the prestigious Members of Faculty Opinions. The articles are commissioned and peer reviewed before publication to ensure that the final, published version is comprehensive and accessible. The reviewers who approved the final version are listed with their names and affiliations.

\section{The reviewers who approved this article are:}

\section{Version 1}

\section{Scott E. Wenderfer}

Pediatric Nephrology, Department of Pediatrics, Baylor College of Medicine, Texas Children's Hospital, Houston, TX, USA

Competing Interests: No competing interests were disclosed.

\section{Richard Furie}

Division of Rheumatology, Northwell Health, Great Neck, NY, USA

Competing Interests: No competing interests were disclosed.

The benefits of publishing with F1000Research:

- Your article is published within days, with no editorial bias

- You can publish traditional articles, null/negative results, case reports, data notes and more

- The peer review process is transparent and collaborative

- Your article is indexed in PubMed after passing peer review

- Dedicated customer support at every stage

For pre-submission enquiries, contact research@f1000.com 